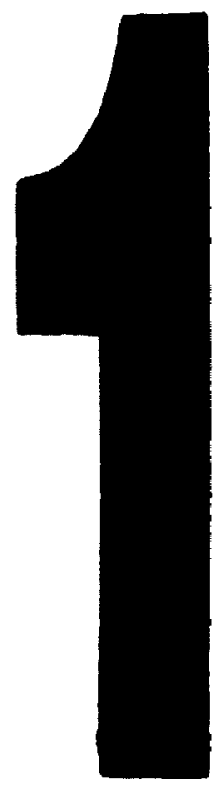

PM-1 3\%"x4" PHOTOCRAPHK MICROCOPY TAREST MES 1010 AMSIISO "2 EOUTALENT

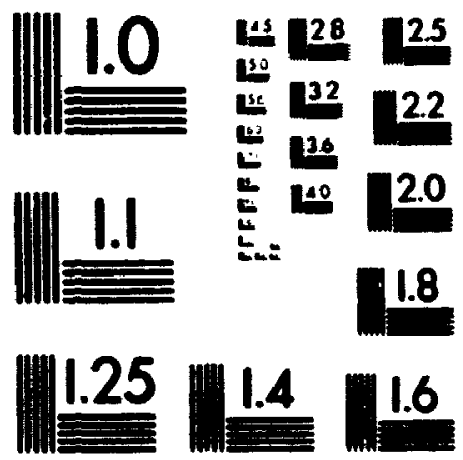

PRECLSIONEM RESOLUTHON TARGETS 
National Library

of Canada

Acquisitions and

Bibliographic Services Branch

395 weingron sired

Oune. Ortano

K1AONA
Bibliotheque nationale

du Canada

Direction des acquisitions et des senvices bibliographiques

395. ne Wemingon

Oname (Orterio)

row the vatrenterence

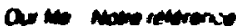

\section{NOTICE}

AVIS

The quality of this microform is heavily dependent upon the quallty of the original thesis submitted for microfilming. Every effort has been made to ensure the highest quality of reproduction possible.

If pages are missing, contact the university which granted the degree.

Some pages may have indistinct print especially if the original pages were typed with a poor typewriter ribbon or if the university sent us an inferior photocopy.

Reproduction in full or in part of this microform is governed by the Canadian Copyright Act, R.S.C. 1970, C. C-30, and subsequent amendments.
La qualité de cette microforme dépend grandement de la qualité de la these soumise au microfilmage. Nous avons tout fait pour assurer une qualité supérieure de reproduction.

S'il manque des pages, veuillez communiquer avec l'université qui a conféré le grade.

La qualité d'impression de certaines pages peut laisser à désirer, surtout si les pages originales ont été dactylographiées à l'aide d'un ruban usé ou si l'université nous a fait parvenir une photocopie de qualité inférieure.

La reproduction, même partielle, de cette microforme est soumise a la Loi canadienne sur le droit d'auteur, SRC 1970, c. C-30, et ses amendements subséquents. 


\title{
SELF-DETERMINATION: PROTECTING THE RIGHTS OF ABORIGINAL PEOPLES IN URBAN AREAS
}

BY

CAROL STACEY-DIABO

B.A. Canadian Studies and Arthropology

\author{
A thesis submitted to the Faculty of \\ Graduate Studies and Research in partial fulfilment \\ of the requirements for the degree of \\ Master of Arts \\ in Canadian Studies
}

Carleton University

OTTANA, Ontario

(April 1995)

1995, Carol Stacey-Diabo 
National Library

of Canada

Acquisitions and

Biblographic Senvices Branch

395 Wellingion Street

Onawa Ontario

kIA ONy
Biblioineque nationale

du Canada

Direction des acquisitions ef

des senices bibliographiques

395. rue Wellington

Ottawa (Ontaro)

KIA ON4

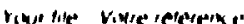

The author has granted an irrevocable non-exclusive licence allowing the National Library of Canada to reproduce, loan, distribute or sell copies of his/her thesis by any means and in any form or format, making this thesis available to interested persons.
L'auteur a accordé une licence irrévocable et non exclusive permettant à la Bibliothèque nationale du Canada de reproduire, prêter, distribuer ou vendre des copies de sa thèse de quelque manière et sous quelque forme que ce soit pour mettre des exemplaires de cette thèse à la disposition des personnes intéressées.

L'auteur conserve la propriété du droit d'auteur qui protège sa thèse. Ni la thèse ni des extraits substantiels de celle-ci ne doivent être imprimés ou autrement reproduits sans son autorisation.

ISBN $\quad 0-612-02997-2$ 
Nom Cavoi favalwas Stacey-Drabo

Dissertation Abstracts International is arranged by brood, guneral subject colegories. Ploase select the one subject which most neorly describes the content of your dissertation. Enter the corresponding four-digit code in the spaces provided.

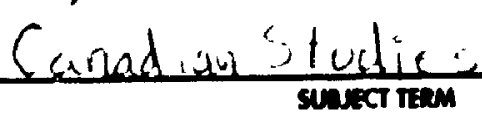

\section{Subiect Colegories}

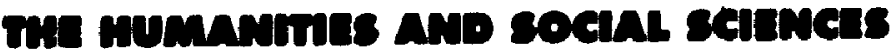

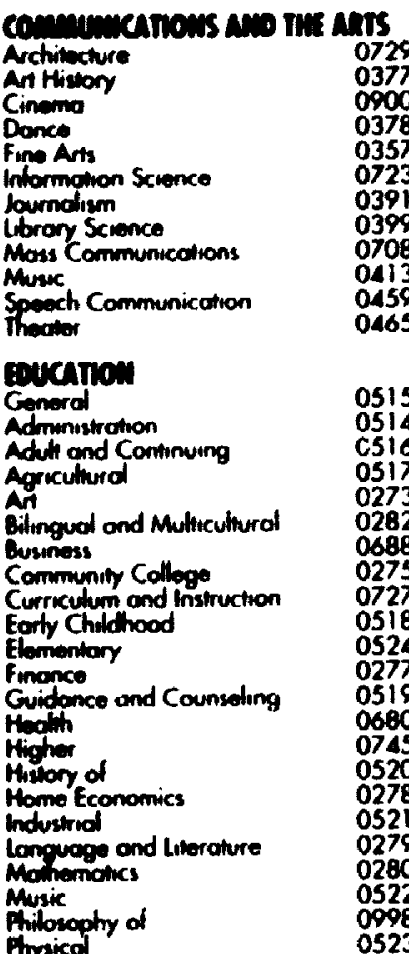

\begin{tabular}{|c|c|}
\hline $\begin{array}{l}\text { sychology } \\
\text { exding } \\
\text { oligious } \\
\text { crences } \\
\text { exondory } \\
\text { ociol Sciences } \\
\text { ocrology of } \\
\text { pexiol } \\
\text { excher Iroining } \\
\text { achnology } \\
\text { ests ond hoosurements } \\
\text { occotional }\end{array}$ & $\begin{array}{l}0525 \\
0535 \\
0527 \\
0714 \\
0533 \\
0534 \\
0340 \\
0529 \\
0530 \\
0710 \\
0288 \\
0747\end{array}$ \\
\hline 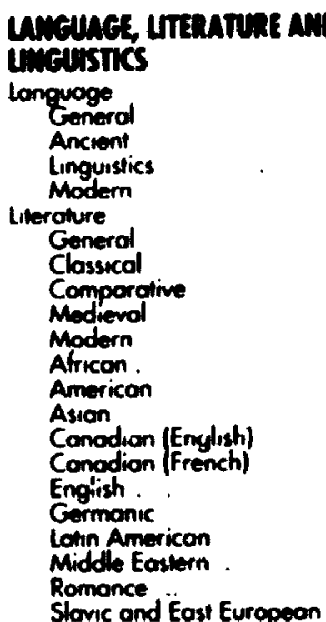 & $\begin{array}{l}0679 \\
0289 \\
0290 \\
0291 \\
0401 \\
0294 \\
0295 \\
0297 \\
0298 \\
0316 \\
0591 \\
0305 \\
0352 \\
0355 \\
0593 \\
0311\end{array}$ \\
\hline
\end{tabular}

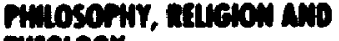

\section{Thelogr}

Philosophy

Religion

Bublical Studies

Clergy

History of

Philosophy of

Theology

socau sarances

Amerncon Shdies

Anthropology

$\begin{array}{ll}\text { A. chrodogy } & 032 \\ \text { Cuthurd } & 032\end{array}$

Business Administrotion

Generol

Bonking

Management

Morketing

Conadion Shudres

Economics

Generol

Agricultural

finonce

History

Labor

Theory

Geogrophy

Geroniology

General
0422

0318

0318
0321
0319

320

032

0469

0323

324

0327

0310
0272

0272

0454

0338

0385

0501

0503

0508

0509

0510

0358

0366

0578

Phriced

0523

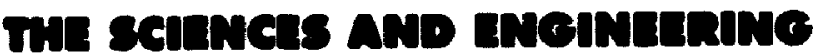

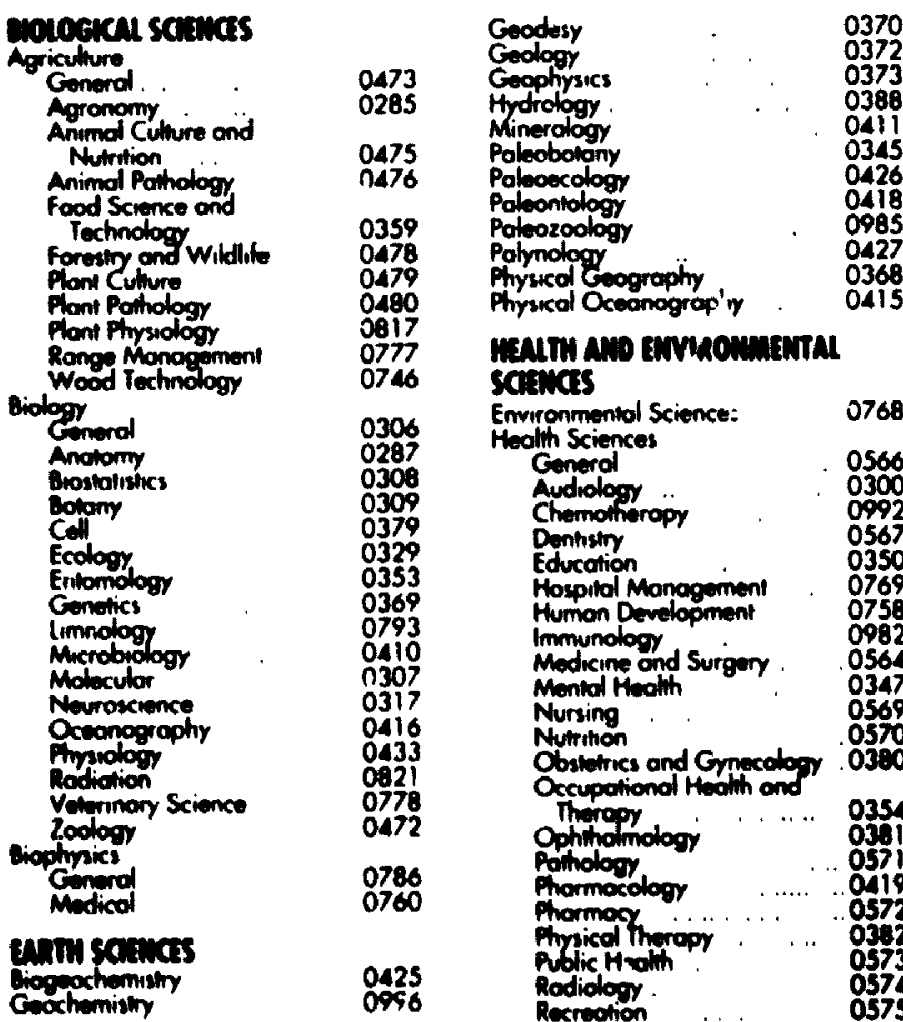

$\begin{array}{cc}\text { Speech Pathology } & 0460 \\ \text { Toxicology } & 0383 \\ \text { Home Economics } & 0386\end{array}$

\section{Mirsicu scatuces}

Pure Sciences

Chemisty

Generol

Anolytical

Biochemisiny

Inorgonic

Organic

Phormoceuticol

Physical

Polymer

Mothemotic

Physics

Genard

Astronomy and

Astrophystes.

Amospheric Science

Atomic

Electronics and Electricily

Elementory Porticles ond

High Enefor..

Fuid and Fosmo

Moloculo

Optic:

Rogliation

Solnd Siow

Sintitic:

Arind Scines.

Aplind Mushonic

Comperer Scinence

0460
0383
0386
Engineering
Genero

Generol . ................. 0537

Aerospoce . ......... 0538

Automotive

Biomedical ............. . OSA

Chemical ...... . ... "OS4?

Chemical . . ....... - OS43

Electronics and Electrical....... OS44

Hegt and thermodrnomics . .034:

Hydroulic ........... 054

Industrial

Morine

054

Motriols Science 079

Muchanicol . ........... O548

Mololwurgy $\quad \ldots . .674$

Mining .. . ............. 055

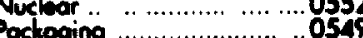

Petroter ..... 0765

Sonitory and Municipol .... . .055e

Srytem Science ................... o7\%

Goutholegy .........................28

Operotions Rewerch..... - 0706

Textils Technology .. . . .............. OPQ4

pranciosy

Conwral

Clinical . ....................... 038

Dulopmentol . 0370

Experimental. . . ...............0823

Induatriol. . . ...................0824

Aersondiny ............................8\%25

Frviologrcol ........................ .989

Pychobidory ................. 0349

Sociol ................................ Q451 
The undersigned recomend to the Faculty of Graduate Studies and Research acceptance of the thesis

- Self-Determination: Protecting the Rights of Aboriginal Peoples in Urban Areas"

submitted by Carol Stacey-Diabo, Hons. B.A. in partial fulfilment of the requirementa for the degree of Master of Arts

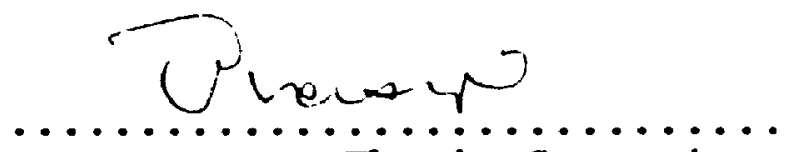
Thesis Supervisor

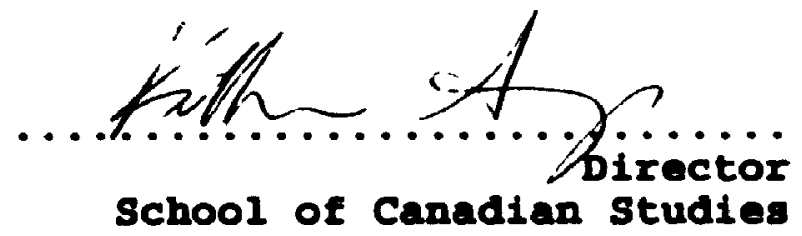

Carleton Oniversity

Ottawa, Ontario

May 1995 


\section{ABSTRACT}

This paper examines the concept of self-determination from an Aboriginal perspective, and the application of these rights to Aboriginal peoples who live in urban areas. One of the greatest concerns for Aboriginal peoples has been the unequal treatment of the various Aboriginal groups by government. This is a particular concern to Aboriginal peoples living in urban areas because of their diversity. As a result of this, they are frequently either neglected by their political leaders, or left out of political negotiations altogether. Mary of the issues identified in this paper were based on certain sections of the Preliminary Integrated Research Plan developed by the Royal Commission on Aboriginal Peoples. Therefore, it is also an attempt to address some of these problems and to develop ideas that might be useful in a discussion on implementing self-determination/selfgovernment in urban areas. 
1. INTRODUCTION . . . . . . . . . . . . . . . . . . 1

2. Self-Deterination: An Aboriginal Perspective . . 4

2.1 The Traditional Political Process . . . . . . . 12

2.2 International Law . . . . . . . . . . . . 19

3. Potential Forms of Governance . . . . . . . . . . 22

4. The Constitutional Process . . . . . . . . . 26

5. Three Orders of Government . . . . . . . . . . 31

5.1 Powers . . . . . . . . . . . . . . . . . 34

5.2 Policies . . . . . . . . . . . . . . . 43

5.3 Institutions . . . . . . . . . . . . . . . 45

6. Political Processes ............... 47

7. Traditional Forms of Governance . . . . . . . . 50

8. Intergovernmental Relations . . . . . . . . . 62

9. Representation and Accountability . . . . . . 69

10. Citizenship: Problems with Defining Rights . . . 73

11. Jurisdiction Issues . . . . . . . . . . . . 83

11.1 Jurisdictional Disputes in Urban Areas . . . . . 88

12. Constitutional Issues . . . . . . . . . . . . . 96

12.1 Canadian Constitution Section 91.24 . . . . . . 100

13. Metis Nation Accord . . . . . . . . . . . . 102

14. Land Base, and Sharing of Natural Resources . . 105

15. Fiscal Resources . . . . . . . . . . . . . 110

15.1 Taxation . . . . . . . . . . . . . . . . . 113

16. CONCLUSION . . . . . . . . . . . . . . . 120

17. APPENDIX 1: Bibliography ............ 122

18. APPENDIX 2: Endnoteg . . . . . . . . . . . . . . 124

19. APPENDIX 3: Title Page ............. 130 


\section{INTRODUCTION}

This paper examines the concept of self-determination from an Aboriginal perspective, and how the rights of Aboriginal peoples living in urban areas might be protected. This issue is controversial, and has generated some heated discussions not only on the part of the federal and provincial governments, but also among various Aboriginal groups.

According to Statistics Canada, the 1991 census indicates the total Aboriginal population has reached 1,002,675. The majority of Aboriginal peoples in Canada do not live on reserves. This fact is of major significance since it has been government policy to give greater recognition of the rights of Aboriginal peoples who live on reserves.

According to figures from the federal government, about three-fourths ( 73 per cent) of all Aboriginal people live outside of reserves. "More specifically, there are approximately five hundred and fifty-two thousand persons of Aboriginal origin"... living off-reserve.

The government limits its financial and legal obligations to Aboriginal peoples who reside in urban areas. They achieve this through the application of discriminatory policies.

The rights that Aboriginal peoples can exercise and the benefits they receive differ from province to province, and in many cases from First Nation to First Nation. The types of rights Aboriginal peoples currently exercise in urban areas are different from those exercised on Indian reserves. The 
rights they do exercise and the benefits they receive are also inconsistently applied across Canada. In addition to this, there are a number of rights which arise out of various treaties and other agreements with both the federal and provincial governments, which are particular to the groups mentioned in these agreements. But the bottom line is that for any of these rights to have meaning, there must be some level of recognition and cooperation between the Canadian government and Aboriginal peoples. This is especially true for Aboriginal peoples living in urban areas.

Due to discriminatory practices on the part of the Canadian government, some Aboriginal groups have not been recognized as possessing Aboriginal rights at all. It has been to the benefit of the government to exclude as many Aboriginal people as possible from being identified as Aboriginal, and therefore possessing certain rights and receiving the benefits. Various levels of government have benefitted from these discriminatory policies. Aboriginal political organizations, and other groups have been encouraged by the government to carry on these discriminatory policies, thereby absolving the government of their responsibilities. Most of the people affected by these policies have been marginalized and forced to live in urban areas, which constitutes a denial of their rights. Many would have preferred to go back to their comannities of origin, but have been unable to do so because of community resistance fostered by past government policies which encouraged discrimination. 
Others groups wanted to form their own communities based on their common Aboriginal backgrounds and ancestry, but they have not been recognized by the Canadian government as possessing Aboriginal status and rights.

There is a need to examine the basis of the right to self-determination, as put forward by various Aboriginal groups and the problems that must be overcome in order for self-determination to become a reality in urban areas. Therefore, this paper will provide a general overview of some of the more important issues concerning self-determination. While many people may believe that the idea that Aboriginal peoples possess the right to self-determination is a new idea, this is not the case. Some of the methods that Aboriginal peoples have employed in order to obtain recognition of their rights to self-determination will be examined, in order to provide a better understanding of the underlying problems that Aboriginal peoples living urban areas face, when trying to secure their rights. 


\section{Self-Determination: An Aboriginal Perspective}

While there are differing views among Aboriginal peoples concerning the ways in which their rights to selfdetermination can be recognized and implemented, they all agree that there is a need for greater recognition and protection of their rights. There are a number of basic principles which are central to their understanding of the concept of self-determination. Many view their rights within a historical context as being derived from their traditional forms of government and the rights they exercised as nations. Therefore it is necessary to look at how Aboriginal peoples governed themselves from a historical point of view.

Aboriginal peoples state that they have exercised their rights to self-determination in various ways throughout history. One of the ways in which Aboriginal peoples exercised their rights to self-determination was through political negotiation on a "nation to nation" basis. This process usually involved the making of treaties. While the terms of these treaties varied in form and content, their purpose was to serve as a guide for the relationships between the Aboriginal peoples and the European peoples they encountered.

Some of these agreements were treaties of "peace and friendship", while others set out entitlements to rights, benefits, goods, monies, and lands. Many of these treaties were written, while others were recited in the oral tradition. 
There are many pre-confederation treaties which the colonial governments signed, but are not recognized as valid by the Canadian government. Aboriginal peoples often refer to these treaties as evidence of their nationhood, and in defining their rights and entitlements, including the right to selfdetermination. There are numerous public records, writings, letters, and legal documents, such as the numbered treaties, which refer to Aboriginal peoples as "nations," and support the contention of Aboriginal peoples that they possess the right to self-determination. One of the most significant treaties that Aboriginal peoples identify as exemplifying their perspective on self-determination, is the Two Row Wampum (Gus-Wen-Teh). This treaty was meant to serve as a guide to the conduct between the two parties to the agreement.

In the introduction to Drumbeat, former National Chief of the Assembly of First Nations, Georges Erasmus, refers to the Two Row Wampum Treaty as symbolizing the original basis of the relationship between European peoples and Aboriginal First Nations. He elaborates on the concepts conveyed in this treaty as the standards that should apply in modern times, in order to establish a better relationship with Canada.

All across North America today First Nations share a common perception of what was then agreed: we would allow Europeans to stay among us and use a certain amount of our land, while in our own lands we would continue to exercise our own laws and maintain our own institutions and systems of government. We all believe that vision is still very possible today, that as First Nations we should have our own governments with jurisdiction over our own lands and people.? 
In a publication produced by the National Association of Friendship Centres, to celebrate the 30th Anniversary of the Friendship Centre Movement in 1988, Erasmus further elaborated on the historical origin of the right to self-determination. Erasmus emphasized the concept of Aboriginal nationhood as defined by the Two Row Wampum, as embodying the type of relationship that Aboriginal peoples should have with Canada.

This Wampum belt was the first treaty signed between our ancestors on the one hand and the early Europeans on the other. In fact, it was between the Haudenosaunee (or Six Nations) and the Dutch and it defines the relationship between separate peoples travelling separately in parallel... on the philosophical level, we maintain that the original relationship of co-existence and friendship, based on tolerance, mutual respect and admiration, must be restored. ${ }^{3}$

Although the original Two Row Wampum treaty was in fact between the Haudenosaunee (Iroquois) and the Dutch peoples, Erasmus felt that this treaty symbolized the principle of equality based on nationhood that should exist between First Nations governments, and the Canadian government. This is in stark contrast to the reality of the application of the Indian Act to Aboriginal First Nations and the discriminatory treatment of other Aboriginal groups in terms of the nonrecognition of their rights. In Drumbeat, Chief Mike Mitchel of Akwesasne discusses the interpretation of the Two-Row Wampum and how the underlying principles still apply in modern times. 
Our belief and faith that we are still an independent nation go back to the first treaty signed in North America, in 1664, when the original European Settlers came to confer with our people in Albany, New York. What came out of that was the Two Row wampum Treaty, in which conditions for our collaboration were agreed to by the two sides.

The Haudenosaunee Confederacy, in a presentation to the Canadian House of Commons Committee on Indian self-Government in 1983, described the meaning of this treaty:

When the Haudenosaunee first came into contact with the European nations, treaties of peace and friendship were made. Each was symbolized by the Gus-Wen-Teh or Two Row Wampum. There is a bed of white wampum which symbolizes the purity of the agreement. There are two rows of purple, and those two rows have the spirit of your ancestors and mine. There are three beads of wampum separating the two rows and they symbolize peace, friendship, and respect.

These two rows will symbolize two paths or two vessels, travelling down the same rivers together. One, a birch bark canoe, will be for the Indian people, their laws, their customs and their ways. The other, a ship, will be for the white people and their laws, their customs and their ways. We shall each travel the river together, side by side, but in our own boat. Neither of us will try to steer the other's vessel.

The principles of the Two Row Wampun became the basis for all treaties and agreements that were made with the Europeans and later the Americans. Now that Canada is a fully independent nation, perhaps it will be possible to strike up the Two Row Wampum between us, so that we may go our ways, side by side in friendship and peace.

The original Two Row Wampum agreement stipulated that each side would refrain from interference in the other's government.

This treaty is important and unique, in that it is not limited to the recognition of the rights of Aboriginal peoples to self-determination, but also recognizes the rights of European peoples to self-determination as well. The interpretation of the "Two-Row Wampum" is based on the Iroquoian tradition of 
oral history. The principle of equality is not limited to the relationship between Aboriginal and non-Aboriginal "nations," but was in fact an extension of their relations with other Aboriginal "nations." Above all, it recognizes the need for equality and mutual respect for each others rights. The rights that the Two Row Wampum recognizes are still applicable within a modern context.

The principles of the Two Row Wampum are applicable to all Aboriginal peoples. The rights of Aboriginal peoples have been limited by the Canadian government's arbitrary categorization and definitions of Aboriginal peoples. The Canadian government has usurped the rights of Aboriginal peoples to self-determination through various methods, but most obviously through colonial policies and legislation which unilaterally control and limit the citizenship rights of Aboriginal peoples. They have violated the right of selfdetermination of Aboriginal people by unilaterally asserting control over them without their consent.

In modern terms, the Two Row Wampun could well be interpreted as the first Aboriginal legal document recognizing and protecting the basic human rights of non-Aboriginal peoples in North America. It recognizes not only the rights of Aboriginal peoples to self-determination, but guarantees those same rights to non-Aboriginal peoples. The interpretation of this treaty goes even further by identifying other rights which flow from the right to self-determination. 
Obviously, there is a need to revisit the "treaty-making process," as a means of exercising Aboriginal selfdetermination as well as, a need to examine the legal, social, and political concepts conveyed through these types of treaties. The Coolican report on comprehensive claimspolicy, Living Treaties: Lastirn Agreements, identifies the treaty making process as the original method of entering into relationships with Aboriginal peoples.

The following passage describes the purpose of the treaties:

Before the arrival of the Europeans, Aboriginal communities were both self-governing and selfsustaining... Since the time of first contact, Eurcpeans and Indian peoples in North America have entered into agreements in an effort to reconcile or accommodate their divergent interests and aspirations. The earliest treaties were signed to formalize military alliances with the Indian nations. When the colonial powers became more firmly established in North America, they sought to assert greater control over the land and, through settlement, to exploit the resources more directly... By entering into these treaties the government formally recognized the existence of Indian political communities and of their interest in the land, and implicity recognized the social, economic, and political rights of the Indian peoples.'

As you can see, the assertion of Aboriginal peoples that they are "nations" is firmly rooted in the past. Their historical claim to "nationhood" is symbolized by the concept of equality conveyed in the Two Row Wampum. The following passage taken from Pathways to Se:--Determination, edited by Leroy Little Bear, reflects the importance they placed on the treaties as a means of establishing equitable relationships with other "nations". 
They hold that their right to self-government is an inherent right derived from the Creator, who gave that authority to all Indian people. They point out that this is a right that pre-dates the Canadian government; thus, the Canadian government was never in a position to create or grant Indian selfgovernment but merely to acknowledge it. They assert, furthermore, that their inherent and historical right to self-government was explicitly recognized by the Crown in the treaty agreements with Indians. Therefore, any power exercised by the Canadian government over Indians, unless it has been freely delegated by Indians, is illegal."

Treaties served not only as guidelines in conducting the political, social, and economic affairs between Aboriginal and non-Aboriginal peoples, but as positive assertions of their rights. In order to address the problems in the current relationship between the parties to these agreements, it might be wise to explore the treaty making process as a possible alternative method of resolving ongoing issues. More importantly, the concepts and principles involved in the treaty process could serve as starting points for future negotiations.

It might also be possible to expand the debate on the right to self-determination, by examining the sources to which Aboriginal people look as explicitly recognizing or implicitly acknowledging their rights. The effort to draw out the common links, as well as, the differences between these sources would serve to illuminate the possibilities for future development.

The topic of Aboriginal self-determination has been the subject of heated debates, often out of fear that recognition 
of Aboriginal governments would somehow threaten the sovereignty of Canada. The fact that Canada, in asserting its rights to self-determination, has trampled on the basic human rights of Aboriginal people in the process seems to have escaped public debate. Aboriginal people do not want to separate from Canada, nor do they want to be assimilated by it. They simply want recognition of their basic human rights, especially their right to self-determination. They basically want the opportunity to determine their own future.

11 


\subsection{The Traditional Political Process}

One of the more difficult problems to address is the link between the suppression of traditional Aboriginal forms of governance, and the erosion of the rights of Aboriginal peoples to self-determination. Only by looking at how the current forms of Aboriginal government differ in nature and scope in comparison to their past forms, do the problems become more clearly focused. The current form of government is a municipal model with very limited powers, and was imposed on Aboriginal peoples by the Canadian government. Aboriginal peoples played no role in the development of this form of governance, nor were they ever asked to participate in its design. Therefore, the imposition of this form of government represents colonial domination to Aboriginal peoples.

Colonial government policies have played a major role in the erosion of the capacity and ability of Aboriginal peoples to govern themselves. The Penner report on Indian SelfGovernment in Canada gives a brief description of how Aboriginal peoples capacity to govern themselves was slowly and gradually restricted over a long period of time.

For thousands of years prior to European immigration, North America was inhabited by many different self-governing aboriginal peoples, speaking many languages and having widely differing cultures and economies. The Royal Proclamation of 1763, which formalized British colonial policy for North America, recognized this situation.

Over the years, however, the initial relationship between Indian people and the British Crown changed. In the evolution of Canada from colonial status to 
independence, the Indian peoples were largely ignored, except when agreements had to be made with them to obtain more land for settlement.

The Indian peoples played no part in negotiating Confederation, or in drafting the British North America Act of 1867 which under section 91(24), assigned legislative authority with respect to "Indians, and Lands reserved for the Indians" to the federal government. The government assumed increasing control over Indian communities, leading to the Indian Act, 1876, which, with minor modifications, remains in effect today. The result over the years, has been the steady erosion of Indian governmental powers.

Under the Indian Act, traditional Indian governments were replaced by band councils that functioned as agents of the federal government, exercising a limited range of powers under federal supervision. The Indian Act also failed to take into account the diversity of Indian peoples and cultures and treated all Indians in Canada as a homogenous group. These two features of the Act still prevail today.

Although the Penner report deals strictly with "Indians" and the Indian Act, other Aboriginal groups have experienced similar situations in regard to the erosion of their rights over time. The long term negative impact of these colonial policies can be seen in nearly every Aboriginal community across Canada. At the same time, acknowledging the existence of Aboriginal governments seems to pose a number of problems for the Canadian government. Traditional forms of Aboriginal government do not fit neatly into modern "Western" definitions of nationhood, therefore, Aboriginal people have either been marginalized, or completely excluded from the political decision making processes in Canada. The rights of Aboriginal peoples to govern themselves have been severely restricted, and in many cases, completely denied. 
The very presence of Aboriginal peoples in Canada poses a moral and legal dilemma for the Canadian state. The existence of their traditional governments, lands, languages, cultures, and histories, brings into question the assertion of complete sovereignty over Canadian territories. In their attempts to establish their nationhood, the Canadian government has systematically undermined and manipulated the rights of Aboriginal nations. The Canadian government has deliberately and arbitrarily limited the capacity of Aboriginal peoples to govern themselves. By not giving full recognition of the rights of Aboriginal peoples, they have maintained their domination and control over this country. The rights of Aboriginal peoples to govern themselves must be recognized to their full scope and capacity.

In the past, when there were conflicts between Aboriginal and non-Aboriginal peoples a political process of negotiation was entered into by way of treaties. The treaty-making process involved many areas of negotiation, and was not limited to land surrenders. There are many pre-Confederation treaties of peace and friendship which symbolized military alliances, political protocols, and often included recognition of certain rights and freedoms. Up until recently the Canadian judicial system would not recognize many of these treaties, and the rights and governing principles that they enumerated. The Penner report on Indian Self-Government in Canada, had this to say about the traditional treaty-making process : 
From ancient times, treaties have been the preferred method for regulating relations between Aboriginal peoples and the Crown. It seems appropriate that in many instances they should form a central part of the modern process for implementing selfgovernment. As the Bella Coola District Council stated:

The proper way to define and establish relations between our Indian governments and the rest of Canada is not through legislation or constitutional amendments, but by a basic political agreement, a covenant or social contract. A basic compact will respect the principle of the equality of peoples. It can be an integral part of the Canadian Constitution while it serves as a constitution confederating Indian Nations in Canada. But as a social contract it cannot be changed without the consent of both sides."

The Canadian courts have chosen to give strict and narrow interpretations of the specific rights defined in written treaties. As a result of these narrow interpretations Aboriginal peoples who have specific treaty rights have not been able to exercise them, or have lost their proper entitlements. This situation needs to be addressed by the Canadian government so that these outstanding issues are resolved. The Royal Commission on Aboriginal Peoples had this to say about the past and future relationship between Aboriginal peoples and the Canadian government.

Looking back at the long history of relations between Aboriginal peoples and the Crown, we can see that profound changes have occurred on all sides since the first treaties were concluded and the first alliances forged. Not all of these changes have been for the better, and not all of the tenets of the original relationship have been honoured. Promises have been broken and great wrongs done. Nevertheless, the time has come for tears of sorrow to be wiped away and our throats cleared of dust, and for $u s$ to speak in a frank and open fashion about our future in this land we share, Aboriginal peoples and newcomers alike.' 
There is certainly a need to change government policles in relation to the interpretation of treaties which are often based on court cases dealing with treaty rights. The majority of these cases usually IImit and restrict the treaty rights of Aboriginal. They often render narrow and legalistic interpretations of their treaty rights, and where the courts instruct liberal interpretations of the rights, the government departments often do not comply with the decisions and there is little that Aboriginal peoples can do in such a situation. The Department of Indian and Northern Affairs, and other government departments are often reluctant to recognize or act on any court decisions which they do not explicitly support. Needless to say, if they are liable in any situation which goes to court, they will hardly be cooperative. Therefore, the nature and scope of treaty rights are often left to the courts to interpret, and even if Aboriginal peoples do win their court cases which deal with treaty rights they experience many difficulties with government non-compliance. It would be helpful if there were an open discussion of the treaty rights that Aboriginal peoples possess and presently exercise onreserve, as well as off-reserve, and any other entitlements which are part of these agreements.

It should be noted, that although the treaty-making process has been the traditional method of entering into agreements with the Canadian government, it is not the only process available. The report of the Royal Commission entitled Partners in Confederation, stresses this idea: 
Nevertheless, legally binding treaties are not the only form that self-government agreements may take. In some cases, for example, political accords between Aboriginal peoples and the federal or provincial governments may have a role to play. Such agreements would lay down broad principles gulding the actions of the parties, even if they would not be directly enforceable in the courts. Their purpose would be to provide an appropriate context within which Aboriginal peoples might implement self-government in a co-operative and nonconfrontational fashion, without fear of government challenge in the courts or disruption in fiscal arrangements.

Nevertheless, there is a heavy emphasis on court rulings and their interpretation of Aboriginal rights in their report. In practice, the Canadian government has adopted a policy of narrowly and strictly interpreting the rights of Aboriginal peoples. Regardless of how liberal the Canadian courts' interpretations of Aboriginal rights may be, Aboriginal people have no method of enforcing court rulings. Moreover, the Canadian governments' adversarial approach to Aboriginal rights issues often leads Aboriginal people straight into the court system. In this system there is usually a winner and a loser, and in the case of Aboriginal rights issues, it is usually the Aboriginal people who are the losers. Obviously, the Royal Commission recognizes that there must be other options open to Aboriginal peoples to pursue their rights to self-determination.

At this point in time, it might be considered a sign of good will on the part of the Canadian government if they were willing to recognize the right of Aboriginal peoples to use their traditional political procesees in negotiating any self- 
government arrangements. For example, if Aboriginal peoples have traditional government structures that they want to uses to establish their system of governance, then they shoula be afforded that opportunity. However, it should be noted that not all Aboriginal groups may have a traditional political process, nor may they want to use it even if they do have one. Other options for the negotiation of self-government arrangements should be open to Aboriginal peoples, including traditional methods of dispute resolution. 


\subsection{International haw}

The Aboriginal peoples of Canada claim that they are "peoples" as defined under international law, and as such, they have a right to self-determination. Moreover, they contend that their right to seif-determination has been violated by past colonial government policies and legislation, and that this situation continues to be problematic today. Aboriginal peoples argue that they exercised this right in the past, and that they continue to be entitled to exercise that right today.

Aboriginal peoples believe that they are entitled to self-determination/self-government under international law as described in the International Covenant on Economic, Social, Cultural Rights and Political Rights:

1. All peoples have the right of selfdetermination. By virtue of that right they freely determine their poljtical status and freely pursue their econor ic, social, and cultural development.

2. All peoples may, for their own ends, freely dispose of their natural wealth and resources without prejudice to any obligations arising out of international economic co-operation, based upon the principle of mutual benefit, and international law. In no case may a people be deprived of its own means of subsistence.

3. the States Parties to the present Covenant, including those having responsibility for the administration of Non-Self-Governing and $T r u s t$ Territories, shall promote the realization of the rights of self-determination, and shall respect that right in conformity with the provisione of the Charter of the United Nations. ${ }^{11}$ 
Aboriginal peoples also point to numerous other sources of historical documentation that recognize their right to selfdetermination either implicitly or explicitly. They contend that their rights to self-determination are systematically being denied by Canadian government. They point to certain policies and legislation, such as the "Indian Act," which has severely limited the exercise of their rights and their capacity to govern themselves.

The claims of Aboriginal peoples to self-determination are not limited to Aboriginal First Nations, but include the Metis and Inuit as well. The right to self-government must be applicable to all Aboriginal peoples, and this should include Aboriginal peoples living in urban areas. Discriminatory government policies have deprived many Aboriginal peoples of their rights. These policies have forced many Aboriginal peoples to live in urban areas, and/or deliberately excluded Aboriginal peoples who chose to live in urban areas. Guaranteeing the right to equal access and equal treatment for Aboriginal peoples living in urban areas is a growing concern.

At various times, Aboriginal peoples have brought their concerns to the International arena, but only as a last resort in attempting to secure recognition of their rights. Not only are Aboriginal peoples looking to the International forums to recognize their rights, but they see international law as setting the standards for negotiating the exercise of 
their rights. It should also be noted that, the present provisions for indigenous peoples do not offer adequate protection of the rights of Aboriginal peoples.

International law is useful to Aboriginal peoples only in setting standards for their treatment by nation states. Aboriginal peoples are aware that the process of filing complaints in an international forum can put some public pressure on the Canadian government to change its policies towards Aboriginal peoples. However, they also recognize that this process is limited, and in the end, it is up to Aboriginal peoples to negotiate for the recognition of their rights.

If Aboriginal peoples are left with no means of resolving many outstanding issues within the Canadian political system, they will be forced to resort to other methods of bringing attention to their problems. Aboriginal peoples have been actively forming relationships with other indigenous peoples around the world in order to share their common problems, but also to bring attention to them. The international arena has provided a forum to discuss their common problems and has increased public awareness of Aboriginal rights issues at the international level. 


\section{Potential Forme of Governance}

At this time, the only form of Aboriginal government that is legally recognized is the "band council" system under the Indian Act. This form of governance was imposed on them, and was based on the "municipal" model of government. This form of governance is very limited in its powers and scope, and under the present situation, is more accountable to the Minister of the Department of Indian Affairs and Northern Development than it is to it's own electors. This form of governance was developed by the Canadian government and as such reflects their political, ideological, and cultural

values. The Penner report on Indian Self-Government in Canada, describes the Indian Act and "band council" system as follows:

The Indian Act is a comprehensive piece of legislation that circumscribes activities in all sectors of Indian communities. It places constraints on the rights of Indian people and bands and limits their ability to govern themselves effectively... Band councils exercise delegated powers. In fact, they are viewed for the most part as extensions of DIAND. Even the Department states that "band governments are more like administrative arms of the Department of Indian Affairs than they are governments accountable to band members". Band councils are the only Indian governmental organization recognized under the Indian Act. But tribal councils, treaty organizations, and provincial, regional and national associations of various kinds play a vital role in the political activities of Indian people. ${ }^{12}$

The report goes on to mention that "the most contentious aspect of the Indian Act was the sweeping power that it gave to the administrators and to the federal government". They further state that the Act presented an illusion of self- 
government in form only and that Indian peoples exercised extremely limited control over their lives.

There are other problems that First Nations peoples have with this system of governance which are too numerous to mention here, but the one consistent theme of the report is that they have found this system to be inadequate in meeting the needs of their communities. Other groups such as the Metis, non-status Indians, and Inuit, do not have government structures like those under the Indian Act. Some groups have only political lobby organizations which advocate on behalf of their special interests. Because of their diverse backgrounds and differing legal status, urban Aboriginal peoples already have some institutions in place to deal with their needs, while others still need to be developed. Aboriginal peoples have not advanced any one particular model of self-government as being the ideal choice, they have consistently stated that each Aboriginal group determine for themselves how they want to be governed. The following excerpt from the Royal Commission on Aboriginal Peoples report on Aboriginal Peoples in Urban Centres, reflects this view:

Presentations at the round table and in public hearings made it clear that no single form of urban Aboriginal government is likely to be appropriate for every city in Canada, given the diversity of communities and populations. Workable models and approaches adopted in centres across the country will need to reflect the diverse circumstances, characteristics and choices of the communities in question. Regardless of the form they prefer, however, urban Aboriginal peoples are unanimous in asserting that they must have a voice in the decisions that affect their daily lives." 
There are many ways in which Aboriginal peoples are influencing and/or participating in various government programs and services, however, this is very limited. Most urban Aboriginal peoples would prefer to administer and deliver their own programs and services. In whatever form they choose to assert their rights to self-determination, Aboriginal peoples clearly want it to be of their own free choice and not dictated to them by the Canadian government. The report on the round table on urban issues elaborates on these views further:

In the future, that voice may take several diverse forms within existing municipal councils and school boards or through autonomous urban institutions mandated to provide services or to exercise a range of government functions. It may also be heard through institutions of urban governance that are extensions of current Aboriginal political structures. Whatever arrangements develop, however, the criteria for their establishment and acceptance have been made clear in testimony before the Commission: responsibility, accountability, and responsiveness to the urban Aboriginal communities they serve.

Obviously, there are some criteria and guidelines that urban Aboriginal peoples would like to ensure are part of any form of urban Aboriginal government, or any other institutions which may be established, particularly in terms of their structure. There needs to be a great deal of flexibility in the ways in which government services and programs are delivered. The diversity of the urban Aboriginal population must be kept in mind, and if certain groups choose to have their own strurtures to deliver services to their own peoples, then ways must be found to accommodate them. The one thing that stands out, appears to be a need for more public 
discussion among urban Aboriginal groups and organizations, as to what types of relationships they want to have with each other. If they can work cooperatively to achieve their goals of greater self-determination, their chances of success will be much higher. But in the end these decisions should be left up to them. 


\section{The Conntitutional Procese}

While the constitutional process should not be viewed as the only means of achieving self-government for Aboriginal peoples, it certainly was useful in facilitating public discussion of the issue. It also explored the possibility of greater self-determination for Aboriginal peoples living in urban areas. Despite the failure of the Charlottetown Accord, it would be premature to dismiss the usefulness of the Aboriginal provisions as set out in the constitutional process simply because it failed. If anything, Aboriginal leaders and those involved in the constitutional negotiating process might look to the Charlottetown Accord as a guide to future development. It is also useful in gauging how far the federal and provincial governments were willing to go in recognizing the rights of Aboriginal peoples in general, and those living in urban areas in particular.

There were a variety of ways in which the rights of Aboriginal peoples could have been recognized and accommodated. Of particular interest to Aboriginal peoples living in urban areas, were the ways in which Aboriginal peoples could have been represented in the judicial syrtem, and Canadian political system. These provisions could serve as the basis for further discussions, and a means of determining future steps toward the achievement of Aboriginal self-determination, especially those living in urban areas. 
However, it should also be noted, that the Aboriginal provisions in the Accord were rejected by the majority of Aboriginal peoples. Although the provisions would have led to significant changes for Aboriginal peoples, especially those living in urban areas, there were a number of problems that Aboriginal groups and political organizations had with the Accord, therefore they need to look at other ways of achieving their goals.

In their report entitled partners in Confederation, the Royal Commission looks at the current constitutional protections offered to Aboriginal peoples. The Commission took the view that section 35 of the Constitution included the right to self-government. In support of their view, they offer this interpretation of the provisions under 8. 35 in the Charlottetown Accord.

In considering these questions, it is helpful to recall exactly what the Charlottetown Accord proposed to do and, more important, what it did not propose to do. The draft legal text of October 9, 1992 included the following provision:

35.1 (1)The Aboriginal peoples of Canada have the inherent right of selfgovernment within Canada.

As the wording indicates, this provision did not claim to create a right of self-government or to grant it to Aboriginal peoples. It affirmed simply that Aboriginal peoples "have" this right, a right described as "inherent". Thus, the draft provision assumed that the right of self-government "already existed" in some sense. The provision was intended merely to confirm the existence of the right and give it explicit constitutional status. Was the Accord correct in recognizing that the right of self-government already existed in Canadian law? This question is the subject of this paper." 
The Royal Commission has concluded that the Constitutional process is not the only means that can be used to achieve Aboriginal self-government. In fact, Aboriginal self-government can take many forms, and should not be limited to the constitutional process. However, now that this process is unavailable, Aboriginal peoples must look for other methods of securing their rights. The Royal Commission recognizes that Aboriginal peoples cannot afford to wait for constitutional recognition of the right of Aboriginal peoples to self-government, therefore they present an argument for immediate discussion and a legal basis for negotiations.

In February 1992, the Royal Commission on Aboriginal Peoples issued a commentary entitled The Right of Aboriqinal Self-Government and the constitution... Since that time the process of constitutional reform has faltered, and the immediate prospects for a further round of negotiations are not bright. However, it is open to question whether cr.s.stitutional amendment is actually necessary to accommodate the inherent Aboriginal right of self-government... In the present paper the Royal Commission considers the possibility that this right already exists in the Constitution of Canada. The paper discusses the historical and legal grounds for the right and how it must be implemented.

In considering the Aboriginal right of selfgovernment in the Canadian constitution, Commissioners do not mean to suggest that the Constitution is the only source of the this right or that the judicial route is the preferred way to articulate it. Other possible sources for the right exist, such as international law, natural law, treaties, and the laws, constitutions, and spiritual beliefs of Aboriginal peoples, and other methods of articulating the right are available, Our aim in this paper, however, is to help fill the vacuum left by the failure of the constitutional reform process and to rekindle discussion of the potential for Aboriginal self-government in the existing Constitution." 
Moreover, the Royal Commission identifies other sources which recognize the right of Aboriginal peoples to selfdetermination. There are other sources which recognize the rights of Aboriginal peoples to self-determination, but they need to be researched and documented. These other sources could provide additional support for the arguments put forth by Aboriginal peoples. Therefore, it is important to carry out research on Aboriginal customs and laws as sources recognizing and/or identifying their rights.

In an article which appeared in the "Globe and Mail" in September 1993, Mr. Justice Rene Dussault, of the Quebec Court of Appeal and co-chair of the Royal Commission on Aboriginal Peoples, defends the views of the Commission:

For some, it came as a surprise when the Royal Commission on Aboriginal Peoples declared that the inherent right of Aboriginal self-government is probably already enshrined in the Constitution... In other words, self government is an inherent constitutional right, one that finds its roots in their original status as independent nations at the time of European contact and in the long history of subsequent relations with both the French and British Crown. In the view of many Aboriginal peoples, when the Constitution was amended in 1982 to guarantee "existing Aboriginal and treaty rights," the inherent right to govern themselves within Canada was one of the rights guaranteed. The Charlottetown Accord would have made that fact explicit, but it would not have created the right: it would only have confirmed it."

The Commission was favourable in their interpretation of the constitution in regard to self-government, and have an enlightened view of Aboriginal rights issues. However, this ituation brings us back to the whole constitutional debate of defining what rights are protected under secion 35 . The 
Canadian government, and in particular the judicial oystem, have traditionally taken a very narrow, legalistic, and adversarial approach as to the interpretation of Aboriginal and treaty rights under the Constitution. Despite the positive interpretation of section 35 by the Royal Commission, Aboriginal peoples will face an uphill battle not only in defining their rights, but also in implementing them. 
In the report on The Right of Aboriainal self-Government and the Constitution: A Commentary, the Royal Commiseion on Aboriginal Peoples described the scope of the inherent right of self-government. They saw it as being "circumscribed" and "Iimited". "Circumscribed" in that Aboriginal governments would be viewed as co-existing with the Federal and Provincial governments, which also exercise "limited" powers. In another of their publications, entitled Partners in Confederation, the Royal Commission restates the same view.

The problems with this approach are not obvious unless one considers that the current division of powers between the Federal and Provincial governments have had significant negative impacts on the ability of Aboriginal governments to exercise the limited powers they have in their present situation. In comparison to the enormous amount of resources, jurisdiction over large areas of land, and the number and scope of powers the Federal and Provincial governments, Aboriginal governments stand a good chance of losing any disputes in relation to the exercise of their powers and/or jurisdictions.

The Royal Commission held that Aboriginal governments would possess some areas of exclusive jurisdiction, while others would be shared with the Federal and Provincial governments. Therefore, Aboriginal governments would have 
some areas of exclusive jurisdiction and others would be overlapping. There is no guarantee that in the areas of overlapping jurisdictions that Aboriginal peoples would not be disadvantaged in any negotiation process.

The Royal Commission also states that, none of the national Aboriginal organizations has expressed an interest in having a voice on national or international issues. If this is truly the case, then the right of self-government might be limited strictly to internal matters of each Aborlginal group, therefore Aboriginal peoples would not have a voice in national and/or international issues that might affect them. Although it may be an accurate observation that none of the national Aboriginal organizations have explicitly stated that they wanted to deal with national or international issues, they may want the opportunity to have some input on these issues in the future. Aboriginal governments may not want jurisdiction over matters of national defence or international affairs, but they may want to have a voice on some matters in these areas, at a future date. However, for the time being most Aboriginal peoples seem to be more concerned with trying to implement local government rathex than participating in larger issues.

At this point, it might be a good idea to look at the concerns expressed by Aboriginal peoples regarding the government's past definition of self-government. Aboriginal peoples have problems with the Canadian government(8) 
definition of their powers under self-government. There is a wide gap between what Aboriginal peoples envision under self-determination, and how the Canadian government wants to define $1 t$, both federally and provincially. Because of these differing views, it would be appropriate to revisit the Penner report on Indian Self-Government in Canada as a starting point. Although the Penner report deals strictly with First Nations and the reserve system, the problems with definitions are still applicable in the present situation.

Witnesses unanimously rejected any band government bill. Their principal criticism was that the proposal involves a delegation of power rather than a recognition of the sovereignty of Indian First Nation governments. Indian governments are not to be regarded as junior governments, they said, and any changes should involve more than a transfer of administrative responsibility. To do otherwise would be to continue old policies.

We are disappointed in the extreme by the narrow and limited version of self-government which the Minister has put forward. It seems deliberately to be slanted to focus discussion on the minor and administrative aspects of self-government, when it could range to far more broad and mature concepts. (Blood Band, Sub $8: 134$ ) 10

Although the Charlottetown Accord offered much more to Aboriginal peoples than any previous government legislation, policies, or political negotiations, there was not enough support among Aboriginal peoples for the Accord. Therefore, even if the referendum had been successful in ratifying the Charlottetown Accord, there would have been a political backlash among Aboriginal peoples. The rejection of the Accord by Aboriginal peoples, only serves to highlight the pressing need to provide alternative methods of achieving Aboriginal self-determination. 


\subsection{Powers}

In their publication, Partners in Confederation, the Royal Commission discusses the nature and scope of powers that Aboriginal self-government would entail, specifically in relation to the Federal and Provincial governments. They also make a number of assertions that Aboriginal peoples may/or may not support. If as the Commission contends, Aboriginal governments are sovereign in their sphere of jurisdiction, then it would not make sense to suggest that there are already limitations on the exercise of their powers, before they have even had an opportunity to discuss this issue. This is not to suggest that Aboriginal governments will be able to exercise unlimited powers, but tha:: any limitations that the Canadian government wants to unilaterally impose would be unacceptable.

Any limitations placed on the nature and scope of the powers of Aboriginal governments, other than those which are administrative in nature, and/or self-imposed, should be the subject of a negotiation process. Aboriginal peoples would find it unacceptable if Aboriginal government powers, and structures were arbitrarily defined and limited without their consent. It should be pointed out that this is the exact problem that they face with Indian Act, and the type of situation that they are trying to avoid. 
There is no doubt that certain areas of jurisdiction, will not be negotiable for Aboriginal peoples, while others will be open to change. By suggesting that the rights of Aboriginal peoples to self-government are already circumscribed by the Canadian Constitution, the Royal Commission is already imposing its own views and restrictions on the exercise of the right. Not to mention that these views appear to maintain the present problams. In their report entitled Partners in Confederation, the Royal Commission on Aboriginal Peoples states that:

The Aboriginal right of self-government is recognized by the Canadian legal system, both under the constitutional common law of Canada and under section 35 . So, while the section 35 right is inherent in point of origin, as a matter of current status it is a right held in Canadian law. The implication is that, although Aboriginal peoples have the inherent right to govern themselves under section 35, this constitutional right is exercisable only within the framework of Confederation."

To even suggest that the rights of Aboriginal peoples to self-government are exercisable only within the context of the Canadian laws is reprehensible, because this ignores the other sources of the right. It also subjects the right to Canadian Constitutional law which severely restricts, and in some cases does not even recognize, the right to self-government for certain groups of Aboriginal peoples. Maintaining the status quo would also keep in place past government practices and policies which promote discriminatory treatment between various Aboriginal groups. For example, some groups of Aboriginal peoples have not been included under the "Indian Act," while other groups such as Indian women do not have 
equal access to the programs and services available to the men in their communities. In addition to this, some groups of Aboriginal peoples do not want to exercise the limited powers that "Band Councils" exercise under the Indian Act. Although they may want to have equal access to the programs and services received by First Nations peoples.

If Aboriginal peoples were to accept this definition of self-government, their rights would be arbitrarily circumscribed and 1 imited before they even had an opportunity to define it for themselves. The process of political negotiation and the whole concept of self-determination would have been circumvented and undermined by accepting this assertion. If the situation were reversed, and it was the Canadian people who were faced with these limitations on the exercise of their rights to self-determination/selfgovernment, then the attempt to restrict these rights would be quite obvious and deemed unacceptable. It only stands to reason that Aboriginal people would feel that this situation is just as unacceptable to them, as it would be to Canadian people.

At the same time the Royal Commission contends that the right to self-government is an inherent right, exercisable without the consent of any other body. If this is truly the case, any limitations on the right would have to be negotiated with the Aboriginal peoples in question. 
It should also be noted that, Aboriginal peoples do not want to be perceived as exercising any form of delegated authority, other than that authority delegated by their own peoples. Their concepts of democracy, and traditional political decision making processes through consensus, indicate that their power base operates from the bottom-up, rather than from the top-down. These processes and concepts would be incompatible in many ways, with Canadian political "system" because it operates on the exercise of power from the top-down.

The Royal Commission takes the argument a step further, by stating that the right of Aboriginal peoples to selfgovernment is limited by section 35. By placing this interpretation on their rights under section 35, the government is already restricting them. By presenting an argument which favours limitations on the exercise of the rights of Aboriginal peoples to self-determination without the consent of Aboriginal peoples, they are inviting failure.

Section 35 does not warrant a claim to unlimited governmental powers or to complete sovereignty, such as independent states are commonly though to possess. Aboriginal governments are in the same position as the federal and provincial governments: their powers operate within a sphere defined by the Constitution. In short, the Aboriginal right of self-government in section 35 involves circumscribed rather than unlimited powers. ${ }^{20}$

This interpretation of Section 35 would seek to limit the powers of Aboriginal governments and as a result of this they would be in a subordinate position, in relation to the Federal and Provincial governments. If this is actually the case, 
then perhaps Aboriginal peoples might want to reconsider the need to entrench their rights in the Constitution. Counterarguments to this view are presented, which takes the position that Aboriginal self-government, as defined through the constitutional process, would put Aboriginal governments on an equal footing with the federal government. They also assert that Aboriginal governments would not be subject to provincial laws, and this appears to be misleading. For example, the Royal Commission mentions that, in 1985 the National Assembly of Quebec gave this definition of the rights of Aboriginal peoples living within the boundaries of Quebec:

(a) the right to self-government within Quebec;

(b) the right to their own language, culture and traditions:

(c) the right to own and control land;

(d) the right to hunt, fish, trap, harvest and participate in wildlife management;

(e) the right to participate in, and benefit from, the economic development of Quebec.." (translation) RCAP Report

This statement further limits the exercise of the right to self-government by making it subject to Quebec laws as well. As you can see, there are now two sets of laws which Aboriginal peoples will be forced to comply with in their attempts to exercise their rights to self-determination. In reality the division of federal and provincial powers and jurisdictions that have been set up under section 91.24 of the constitution leave little, if any, room for Aboriginal governments. In order for Aboriginal governments to exercise their powers, certain areas of jurisdiction would have to be 
vacated by both levels of government. It would be unwise to believe that any negotiations to vacate these areas will be an easy one. Any discussion of Aboriginal self-determination which does not fully address the provincial/territorial perspectives on this issue would be seriously misguided.

Although Aboriginal peoples agree with the view that Aboriginal governments should be sovereign in their spheres of jurisdiction, many believe that this will be difficult to achieve because this is not the reality right now. This is a theoretical and ideological approach, and does not address or reflect the adversarial situations which Aboriginal peoples have experienced in dealing with both levels of government. With both the federal and provincial governments trying to restrict the powers of Aboriginal governments, the constitutional process is not the ideal way to gain recognition of the right of Aboriginal peoples to selfdetermination. In any case, Aboriginal peoples would have to agree to any limitations that might be imposed on their rights to self-determination through their inclusion in the Constitution.

Present Aboriginal governments are not in the same position as the Federal and Provincial governments when they were negotiating their areas of jurisdiction at the time of Canadian Confederation. Both the federal and provincial levels of government had the opportunity to negotiate the terms of their entry into Confederation, but Aboriginal 
peoples were simply listed as one of the areas that the federal government had jurisdiction over under section $91(24)$. As a result of this, Aboriginal governments are not on the same footing as the Federal and Provincial governments are in regard to the Constitution, since they were not afforded an opportunity to negotiate the terms of Confederation. The Penner Report on Indian Self-Government in Canada, lends support to this point of view.

The Indian peoples played no part in negotiating Confederation, or in drafting the British North America Act of 1867 which, rader section 91(24), assigned legislative authority with respect to "Indians, and Lands reserved for the Indians" to the federal government. The government assumed increasing legislative control over Indian communities, lead to The Indian Act of 1876, which, with minor modifications, remains in effect today. The result, over the years, has been the steady erosion of Indian governmental powers. ${ }^{22}$

Although the Royal Commission has elaborated on the concept of separate but equal sovereign powers being exercised by the three orders of government, the reality is far from this ideological concept. The federal and provincial governments are only sovereign in certain areas, which have been mutually agreed upon. Their overlapping areas of jurisdiction are shared and the governments are more directly accountable to the people they serve. Under the current situation, the only legally recognized form of Aboriginal governments are "band councila" under the Indian Act. In most cases, these governments are more accountable to the federal government than they are to their own people. To envision present Aboriginal governments as being separate but equal, ignores the differences in the social, political, and economic 
situations. The gap between the reality and governmental policies on Aboriginal self-government is a large one, therefore any move toward greater Belf-determination will probably be a difficult one, given past experiences in negotiations with the Canadian government. Not to mention the conflicting views on self-government, not only between the various Aboriginal groups, but also between the federal and provincial governments.

The fact that Aboriginal peoples played no role in confederation also lends support to the idea that Aboriginal peoples were indeed separate nations, that had their own forms of governance. There was never any debate about them joining confederation. Their relations were dealt with through a foreign affairs office and as military enemies or allies at the time of confederation. The Canadian government gradually assumed greater control over their territories and their rights, as they ceased to be a military threat. At this point the Canadian government has a stranglehold on the lives of Aboriginal peoples, and they are struggling to free themselves from it.

As part of their struggle for self-determination, Aboriginal peoples want to define for themselves what types of powers their governments will be able to exercise, including its structure. The federal and provincial governments must respect the rights of Aboriginal peoples to choose their own systems of governance, whatever forms they 
may take. Aboriginal peoples must be free to choose for themselves how they will be governed. The temptation for the Eederal and provincial governmente to interfere with thie process will be one of the greatest difficulties to overcome. The Federal and Provincial governments may have to give up some control over Aboriginal peoples in order for Aboriginal self-determination to become a reality. Obviously, this must be accomplished in an orderly manner, and through a tactful negotiation process if Aboriginal peoples are to succeed in their efforts to take control over their future. 


\subsection{Policies}

At this time, the Canadian government controls the policy making process for Aboriginal peoples in most areas, including defining how Aboriginal peoples will achieve selfdetermination. Aboriginal peoples have taken over some programs and policies developed by various levels of government, but have had little input into their development. In many cases their effectiveness is limited by strictly enforced policy and program guidelines, and compliance is coerced through threats of funding termination. Aboriginal peoples have little freedom in the way these programs are administered and virtually no control over their development. There is obviously a need for any Aborisillal government to control the policy making process, in order to meet the needs of their people. Any efforts by outside governments to control the policy making process only serve to undermine Aboriginal governments. The Canadian government must be willing to give up, and/or share control over this process.

As far as the development of policies for Aboriginal governments is concerned, it is highly unlikely that it would differ dramatically from the present form and process. Although there are sure to be some differences in the way the policies are implemented. Aboriginal governments may want to take over the development in some policy areas in order to ensure that the individual needs of each community are served, and are tailored to their own concerns. While other 
communities may be satisfied with simply administering the existing programs and services. In the end, Aboriginal peoples want their governments to be accountable to their communities in some form or other, and it is ultimately this accountability and underlying principles which will serve as a means of developing policies. The unique circumstances and characteristics of each Aboriginal community, and should be culturally appropriate and sensitive to the people they serve.

It should also be noted, that Aboriginal governments have been more accountable to Canadian government ministers and bureaucrats, especially the Department of Indian and Northern Affairs, than they have been to the people who put them in office. Aboriginal peoples want to develop their own programs and deliver their own services so that they can meet their own needs. Given the large number of people employed by the Department of Indian Affairs and Northern Development to deliver programs and services and the associated costs, Aboriginal people feel that they could do a more effective and cost efficient job in this area, especially policy development and implementation. 


\subsection{Institutions}

Any institutions which are established to implement Aboriginal eelf-government, must be developed and run by Aboriginal peoples. Institutions of self-government can be devoted to a wide variety of issues and/or problems, but ultimately they must be accountable to the people whom they are meant to serve. In the following extract, the Royal Commission on Aboriginal Peoples acknowledges that in order to implement self-government no one model can be used:

Self-government means different things to different Aboriginal groups. For some, it may mean reviving traditional governmental structures or adapting them to modern purposes. For others, it may mean creating entirely new structures or participating more actively in new or existing institutions of public government at the federal, provincial, regional or territorial levels. For certain groups, it may involve developing structure of public government that would include all the residents of a particular region or territory... No single pattern or model can be adequate, given the great variety of aspirations and circumstance among Aboriginal peoples.23

The same thinking would apply in the development of institutions of self-government. These institutions should reflect the needs and aspirations of the people whom they were created to serve. Since many Aboriginal peoples have had only limited experience, in establishing and running institutions of self-government (ie. band councils), it is to be expected that they will face many problems. Some communities are more sophisticated and have already established some institutions of self-government and/or taken over the delivery of programs and services to their people, while others are just beginning 
to do so. Establishing and running these and other Institutione wi1l not be easy, but it is a neceseary step on the way to self-determination. Aboriginal peoples will make some mistakes in the process, but they will ultimately be responsible for correcting them. And it is in making mistakes, that they will learn to become effective and efficient. 
6. Polltical Procenges

Aboriginal peoples must be able to develop their own political processes and not be bound by the established Canadian political 1deologies. These processes were meant to serve Canadian peoples and not Aboriginal peoples. The customs, cultural values, and traditions associated with the Canadian political system do not accommodate or reflect Aboriginal customs, cultural values, and traditions. There needs to be some recognition of the fact that Aboriginal peoples have different political systems and methods of governance that must be taken into account under any selfgovernment arrangements. Aboriginal peoples should not be expected to become part of the Canadian political system because this would undermine their rights to selfdetermination. If they should choose to participate in the Canadian political system, then their participation should be based on a process of negotiation. In the past, much of their participation has been the result of military force, coercion, and/or crisis situations. Cooperation, rather than subjugation under government legislation, should be the basis of any future relationship.

There is not only a need to look at past problems the government has had in dealing with Aboriginal peoples, but also to avoid getting stuck on these issues. For example, rather than seeing the Charlottetown Accord as a failure, it should serve as a guideline to future development. Although 
the constitutional process was certainly not the way for Aboriginal peoples to achieve greater self-determination based on their aspirations.

All Aboriginal peoples want to assume greater responsibility and control over their communities, but in order to achieve this, they must have more formal relationships with non-Aboriginal governments. There is a need to ensure that the voices of Aboriginal peoples and their governments are heard in the political arena. And they must be given an opportunity to protect the interests of their people through the methods that they put in place under any form of governance. The Canadian government will have to be flexible when it comes to the various traditional political processes and methods of decision making that Aboriginal peoples may want to put in place. Denial and suppression of traditional Aboriginal political processes has had a long history in Canada, and there is sure to be resistance to any changes in this area.

Perhaps the greatest difficulty to overcome on the part of the Canadian government will be the public recognition and acceptance that Aboriginal peoples are similarly entitled to the right self-determination. The Canadian state has, more often than not, exercised its rights to self-determination at the expense of the Aboriginal peoples. Aboriginal peoples can no longer be deprived of their rights to selfdetermination/self-government simply based on the fear that 
they may abuse their powers. To maintain the status quo, would be to condemn Aboriginal peoples to suffer the consequences of the current inequalities and abuses they have suffered under colonialism for generations to come. 
The fact that the Canadian government deliberately suppressed traditional Aboriginal governments, is still a point of contantion for Aboriginal peoples. Past and some present government policies were designed to undermine and destroy traditional social, political, and economic institutions and/or practices. Assimilation was a matter of general policy towards all Aboriginal peoples. As a result of repressive policies, many Aboriginal peoples were forced to give up their traditional ways of governing themselves, and submit to a system of governance which they did not support. Many Aboriginal peoples believe many of their rights were violated by the Canadian government. The government outlawed their traditional practices in what ever form they occurred.

Attendance at Potlatch functions was prohibited by law as late as 1951, and jail sentences were handed down to violators. All of the ceremonial items and symbols of government were seized by the federal government. Despite the return of some items, a number have not been returned and are dispersed in museums in Canada and abroad. People who lived according to the Potlatch had to practise their religious beliefs clandestinely and were forced to live under a system of government imposed on them. Despite this suppression, traditional governmental systems like that of the Haudenosaunee and the Potlatch have not disappeared.

The Canadian government imposed non-A\} -, ginal forms of governance on First Nations peoples through the Indian Act, these actions were widely resisted by Aboriginal peoples. The Penner report on Indian Self-Government makes this point quite explicitly. They state that it was a matter of 
government policy to replace traditional Aboriginal

governments under the Indian Act of 1876 .

Under the Indian Act, traditional Indian governments were replaced by band councils that functioned as agents of the federal government, exercising a limited range of powers under federal supervision. The Indian Act also failed to take into account the great diversity of Indian peoples and cultures and treated all Indians in Canada as a homogeneous group. These two features of the Act still prevail today. ${ }^{2 s}$

Other Aboriginal groups such as the Metis were given no selfgovernment cptions. They were forced to participate in a political system which did not adequately represent them and was not accountable to them.

The Canadian government forcibly installed the present system of governance under the Indian Act, As a result of this many Aboriginal groups took their traditional ways underground. Those who rebelled were punished with jail sentences, and some even died in their struggle to maintain their traditional governments.

The Canadian government suppressed the Haudenosaunee government by jailing its leaders and refusing to give it official recognition. In 1924, the council hall at the Six Nations Reserve was raided by the Royal Canadian Mounted Police (RCMP). All official records and symbols of government were seized and have never been returned. The system of "band councils" mandated in the Indian Act was installed in its place... The second example is that of the Potlatch, a system used by many First Nations on the West Coast. From time to time, community or national leaders call assemblies which are widely attended. Through ceremony, song, dance and speeches, new leaders are installed in office... Political councils are held and decisions are made... As was the case with the Haudenosaunee, the Potlatch was outlawed by the Canadian government. 
As a result of these oppressive policies, many Aboriginal peoples have lost the knowledge of their traditional forms of governance, and may be unable and/or unwilling to reestablish them. At the same time, other groups may have a form of government that has been suppressed by the "Band Council system," but still exists. The legitimacy of these systems, some of which went underground, needs to be acknowledged. Often these two forms of government find themselves competing against each other for 1 imited resources, and often to the detriment of their communities. These situations need to be resolved, and only one form of government should remain. There are a number of ways in which the two systems can either be integrated, or elements adopted to fit the present situation. Other forms of government which reflect certain elements of the traditional value systems could be developed and may actually take the place of the "Band Council system." These adaptations could be accomplished in a number of ways, but ultimately this decision should be left up to the individual communities involved. They have to be able to determine their own priorities and set up their system of government in their own wiy, whether or not that form of government is traditional. The bottom 1 ine is that the form of governance must be of their own choosing, and not dictated to them by outsiders.

The traditional forms of government existed alongside those which were developed and/or imposed by the canadian government. The recognition, and restoration of traditional 
Aboriginal political institutions may hold the key to future relationships between Aboriginal and non-Aboriginal peoples in Canada. Receiving recognition of their right to use their traditional forms of Aboriginal government is extremely important. One has only to look at how these traditional Aboriginal governments have been undermined by past colonial government policies in order to understand the significance of it. Historically, the Canadian government has taken the view that Aboriginal peoples would be "assimilated" into Canadian society with or without their cooperation. There was no room for Aboriginal peoples, or their governments, in this vision of Canada, except perhaps as tokens. As Rick Ponting points out in his book entitled Arduous Journey: Canadian Indians and Decolonization, the Canadian government has had long standing colonial policies aimed at the destruction of traditional Aboriginal societies:

If there has been a central pillar to Canadian Indtan policy, it has been the goal of assimilation. While the terminology has varied among "assimilation," "integration," "civilization," and "moving into the mainstream," the policy has remained virtually urialtered; Indians were to be prepared for absorption into the broader Canadian society. It was expected that eventually Indians would shed their native languages, customs, and religious beliefs and become self-sufficient members of the modern Canadian society and labour force... In 1920, for instance, the deputy superintendentgeneral of Indian Affairs spoke as follows to a special committee of the House of Commons on proposed changes in the enfranchisement provisions of the Indian Act: "our object is to continue until there is not a single Indian left in Canada that has not been absorbed into the body politic and there is no question, and no Indian Department, that is the whole object of this Bill."... 
Gibbons and Ponting further assert, that the policy of assimilation of Indian/Aboriginal peoples has not been abandoned nor changed fundamentally in the past hundred years. It is important to understand the aspirations of Aboriginal peoples in regard to self-determination, including their historical basis.

The idea of "assimilating" Aboriginal peoples into Canadian society seems innocuous enough, except when one looks at the impact it has had on Aboriginal societies. Aboriginal peoples have come to view policies based on "assimilation" as genocide. "Assimilation" means the destruction of Aboriginal societies and their traditional forms of government. All of their traditional practices, and especially their forms of government were to be replaced by supposedly superior models. In fact, they were replaced by a form of government which was colonial in nature, and one which the Canadian government could control and manipulate. The underlying ideology of these actions was racist and based on white domination. Therefore, Aboriginal peoples have rejected "assimilation" as a means of accommodation within Canadian society. As a result of these racist policies, they have experienced wide scale social breakdowns. They are in the process of trying to stem these problems, but have had limited success because they have little control over their current situation.

When Aboriginal peoples speak about a healing process, they do so with the knowledge that there has been much damage 
done to their peoples through destructive and abusive government policies. Therefore, they feel that there is a need to address the damages done to Aboriginal communities and to aid them in their healing process. Recognition of their rights to self-determination/self-government could be the beginning of that healing process. Despite the heated discussions likely to occur around these issues, it is important for Aboriginal peoples to persevere in their efforts to gain recognition of their rights. More importantly, it is up to Aboriginal peoples to discuss and define and for themselves what their rights to self-determination entail. There should be more public discussion among Aboriginal peoples concerning self-determination so that they can develop common positions and accommodate their differing interests and goals, on various issues. There is no better place to start the debate than by looking at the different traditional forms of government, and the principles by which they operated. Their customary laws and traditional political processes define and elaborate on their individual and collective rights and freedoms, as well as, providing us with a basic understanding of their traditional governmental structures.

Before European contact traditional forms of Aboriginal governance had many similarities. One of the key concepts on which they operated was based on equality. This concept was entrenched both in their traditional religious belief systems. as well as, in their political ideologies. Aboriginal forms of governance usually had no visible divisions between their 
political and religious institutions. These values and principles formed the foundations of their traditional political systems and must be taken into consideration in any exploration of Aboriginal governance. While some Aboriginal peoples had complex political processes, others were very simple in their organization. Each "nation" exercised its own authorities, and usually enforced their laws in ways which were consistent with their traditional value system. Their concepts of self-determination extended beyond the collective rights that they exercise as peoples, and were realized in their views on individual rights and freedoms.

It should be noted that, for most Aboriginal peoples there was no visible division of "church and state" as there was for European peoples. However, this situation changed as Aboriginal peoples were exposed to European institutions, and divisions did occur over an extended period of time. Their political leaders were usually people who were spiritual role models and not just Heads of State. They had a "holistic" approach in their political systems, in that an issue had to be debated from a variety of views and a compromise reached. The integration of their traditional social and spiritual value systems into their political systems made their governments more responsive to the needs of the people.

Equality was one of the key pinciples of their political systems, especially in the decision making process. The integration of their spiritual and political ideologies, and 
emphasis on equality, is reflected in the following quote by

Oren Lyons an elder of the Haudenosaunee:

There is another fundamental understanding in Indian goverrment and it is that all life is equal. Whether it is the growing life of trees, plants, or animals, or whether it is human, all life is equal. Furthermore, all human beings, black, red, yeilow, and white are equal and of the same family.

Non-interference of government in the personal lives of their citizens was also an important element of their political systems. For instance, under the Iroquois system, the chiefs were not usually not allowed to use force or manipulation in attempting to get support for their issues, or they could be punished for it. Persuasion by logic and arguments put forward to gain support from the people were the only methods that were condoned.

There is a need to understand the basic principles and concepts underlying traditional Aboriginal forms of governance, including their rights and freedoms. While Aboriginal citizens usually exercised a great deal of individual freedom, these freedoms were usually balanced with the obligation of the "individual" to the "nation." This ensured that both individual and collective rights were respected and that there was a balance between their rights.

The principle of equality is reflected in many areas, but most visibly in the traditional decision making process which was based on consensus. Consensus decision making was based on individual and collective participation, and arrival 
at mutualiy agreeable decisions. It should also be noted, that there are other sources where information can be gathered on the values and traditions that were important to Aboriginal peoples, especially their oral traditions and story telling. These stories illustrate the values and principles that were deemed necessary to the survival of both the individual and the community and serve a variety of purposes.

In Pathways to Self-Determination, Oren Lyons and Tom Porter both gave their perspectives on traditional government, as well as, discussing the political decision making processes of the Haudenosaunee (Iroquois Confederacy). They reflect the integration of "church" and "state" in their political ideologies. They also identify some of the underlying principles and ideologies of their traditional government.

In their model of self-government, native Indian leaders place great importance on traditional political values and philosophies. Consequently, a recognition and appreciation of those ideas is necessary to an understanding of both the historical roots and the future directions of Indian government... Traditionally for the native Indian, involvement with his tribe was integral to his existence as a human being. Ostracism, as Tom Porter points out, was tantamount to a living death. While the individual's inclusion within the wholeness of his tribe was critical to his existence, there still prevailed a respect for individual autonomy and freedom. This is probably best exemplified by the absence in traditional Indian political thought of hierarchical authority, which is integral to Western political and economic organization. Respect for the individual also found expression in decision-making by consensus. Majority rule, as Oren Lyons tells us, only serves to perpetuate factionalism and minority agitation." 
Much can be learned from an examination of traditional Aboriginal forme of governance and the ideological foundations of the societies that generated these governments. It is clear in the case of Aboriginal governance, that one has to look to the past in order to understand the problems of the present. Therefore, any sources of information which can offer some sort of insight on the traditional forms of governance should be explored.

The idea that Aboriginal peoples existed in a state of lawlessness prior to the arrival of Europeans 18 a false and racist assumption. This idea has led to the unreasonable fear that if Aboriginal peoples returned to their traditional forms of government, it will result in a state of anarchy. This is an incorrect assumption, since Aboriginal people do not exist in a void. They need to maintain an ongoing social, political and economic relationships with the Canadian people, and their governments. In fact, many of the underlying principles of Canadian and American constitutions and governmental principles and processes are based on traditional forms of Aboriginal governance, therefore they have much more in common with Aboriginal peoples than they realize.

The fear of traditional forms of governance must be overcome, so that peace and order can be maintained. Aboriginal peoples want their rights to self-determination to be respected, which 18 not the case in the present situation. They are also interested in strengthening their relationships 
with the Canadian peoples, and want to protect their righte In a peaceful manner. Recognizing the right of Aboriginal peoples to use their traditional governmental structures would be a step in the right direction.

Developing a basic understanding of traditional Aboriginal values and principles would be helpful in illuminating these forms of governance. For instance, in examining some of the basic principles and values incorporated in traditional government of the Haudensaunee (Iroquois), Lyons and Porter, identify spirituality as a key element:

Finally, both contributors underscore the importance of spirituality in traditional native political thought. Spirituality was the foundation and the nexus of traditional social and political organization. Through spirituality the natural order of things was revealed and man's proper relationship to nature was established - a relationship based on respect and preservation, not exploitation. Spirituality underlies the argument that Indian government has an obligation to maintain the faith for future generations. Is it little wonder that Canada's native Indian peoples resent an externally imposed political order that is highly bureaucratic, secular, and conducive to factionalism. 30

If Aboriginal peoples want to return to their traditional forms of governance, there are sure to be some differences that would have to be accommodated by the canadian governments. There are certainly some differences that would have to be accommodated, in order for these governments to function properly. It should be noted that, regardless of the form and structure, Aboriginal peoples want their governments to be accountable to them and representive of their people. 
The challenge for the future will be to educate the general public about these issues, and to promote greater understanding of traditional forms of government, including the role that Aboriginal peoples have played in building this country. All too often the achievements and contributions of Aboriginal peoples are ignored, perhaps it is time to change this situation. 
To date, perhaps the most effort made by the Canadian government to accommodate the aspirations Aboriginal peoples were contained in the Charlottetuwn Accord. It offered Aboriginal peoples many opportunities to participate in the Canadian political system. It would have given them some seats in the Senate, future discussions on representation in the House of Commons, and the possibility of appointing an Aboriginal judge to the Supreme Court of Canada.

\section{Aboriginal Peoples's Representation in the Senate}

Aboriginal representation in the Senate should be guaranteed in the Constitution. Aboriginal Senate seats should be additional to provincial and territorial seats, rather than drawn from any province or territory's allocation of Senate seats.

Aboriginal Senators should have the same $r$ le and powers as other senators, plus a possible double majority power in relation to certain matters materially affecting Aboriginal people. These issues and other details relating to Aboriginal representation in the Senate (numbers, distribution, method of selection) will be discussed further by governments and the representatives of the Aboriginal peoples in the early autumn of $1992(*) .31$

Aboriginal peoples were to be guaranteed representation in the Senate under section 11. Institutions, sub-section "A. The Senate" clause (9). Discussions were also to be held on representation in the House of Commons under 11 . Institutions. sub-section C. clause (22). 
22. Aboriginal Peoples' Representation

The 18sue of Aboriginal representation in the House of Commons should be pursued by Parliament, in consultation with representatives of the Aboriginal peoples of Canada, after it has received the final report of the House of Commons Committee studying the recommendations of the Royal Commission on Electoral Reform and Party Financing. $(*)^{32}$

This section could have offered the opportunity to Aboriginal peoples to have a voice on many issues. The other clause which would have given Aboriginal peoples the upportunity to participate in the Canadian political system, was section 11. Institutions, sub-section "B. The Supreme Court" clause 20. 20. Aboriginal Peoples' Role

The structure of the Supreme Court should not be modified in this round of constitutional discussions. The role of Aboriginal peoples in relation to the Supreme Court should be recorded in a political accord and should be on the agenda of a future First Ministers' Conference on Aboriginal issues. $(*)$

Provincial and territorial governments should develop a reasonable process for consulting representatives of the Aboriginal peoples of Canada in preparation of lists of candidates to fill vacancies on the Suprem. Court. $(*)$

Aboriginal groups should retain the right to make representations to the federal government respecting candidates to fill vacancies on the Supreme Court. $(*)$

The fedriral government should examine, in consultatior with Aboriginal groups, the proposal that an Aboriginal Council of Elders be entitled to make submissions to the Supreme Court when the court considers Aboriginal issues. $(*)^{33}$

In addition to these guarantees, there was a provision ior future participation of Abcriginal peoples at First Ministers Conferences on any issues directly affecting them. Although recognition of the "inherent right of self-government" was a key issue, it appears that there would have been problems 
implementing it with the restrictions that were being applied, especially in urban areas. There were several clauses numbered from 41-48, under section IV. First Pegples, which appear to deal only with the situation of Aboriginal peoples with a recognized land base. Even the sections dealing with the Metis Nation Accord appear to apply to a specific land base. Therefore, urban Aboriginal peoples who do not have an identifiable land base, would have been excluded from these self-government negotiations.

As a result of these problems, self-government arrangements would probably not have been applicable in urban situations, where there are Aboriginal peoples from different nations. Aboriginal peoples living in urban areas would have had to prove that they were entitled to the "inherent right of self-government." since urban Aboriginal peoples are not "homogeneous", they would not have met the basic requirements to enter into self-government agreements. In addition to this, it is unclear, whether the provisions for Aboriginal participation and representation in the Canadian political system would apply to urban Aboriginal peoples. Aboriginal political groups would also resist the application of this right in urban areas. Therefore participation in the Canadian political system would probably have been the only option left open to Aboriginal peoples. Urban Aboriginal peoples should be concerned about ensuring recognition of their rights to se: f-government, especially in view of the fact that the Royal Commission appears to reflect government biases in dealing 
with Aboriginal peoples living in urban areas. The following excerpt was taken from an information release on selfgovernment:

In practice, then, what steps must an Aboriginal group take to implement its inherent right of selfgovernment? We will deal here only with the central case: a group that constitutes a distinct entity and possesses its own lands, whether these be held under Aboriginal title, treaty provisions, order in council, occupation, or otherwise. The case of Aboriginal groups without any form of land base is different and poses a range of complex problems that cannot be dealt with here. p. 44

The implications of this statement should concern all urban Aboriginal peoples. If the Royal Commission is not going to address the issue of urban Aboriginal government, then who will? Their approach to self-government appears to be biased in favour of First Nations, and other Aboriginal groups with an identifiable land base. To limit the right of selfgovernment to those Aboriginal groups with a land base would leave out nearly 708 of the Aboriginal population. Statistics on Aboriginal peoples taken from the Canadian census indicate that there has been a major and on-going migration of Aboriginal peoples from reserves, and that the permanent and long term urban Aboriginal population is on the rise. Government policies concerning the provision of services and programs for Aboriginal peoples living in urban areas is inconsistent and/or non-existent in many cases. The provision of programs and services to Aboriginal peoples living in urban areas is particulariy important to their survival in these areas. Not only do they fail to provide programs and services for Aboriginal peoples living in urban areas, but they 
discriminate between on-reserve and off-reserve populations. Therefore, when Aboriginal peoples leave their communities they lose their entitlements to certain rights and benefits which are available only if they reside in their communities. Not only do they discriminate between Aboriginal peoples who reside on and off-reserve, but they also strictly control who receives any benefits at all. In their efforts to reduce their financial and legal obligations to Aboriginal peoples, the government regulates and controls who may receive Aboriginal status and rights, often to the disadvantage of the Aboriginal communities and the individuals involved. The government has also excluded certain groups of Aboriginal peoples from exercising their Aboriginal and treaty rights through various methods, but most obviously through discrimination based on their residency. These exclusionary and discriminatory practices on the part of the Canadian government must come to an end, otherwise urban Aboriginal peoples will face even greater inequalities than they are currently experiencing.

In terms of inter-governmental relations, based on the provisions for self-government contained in the Charlottetown Accord, both the federal and provincial governments would have occupied the areas of jurisdiction until Aboriginal governments could take over. When Aboriginal governments indicated that they were ready to assume their jurisdiction, both levels of government would have vacated these areas. It is only reasonable to assume, that there would have been 
numerous disputes arising in urban areas concerning Aboriginal jurisdictions. In fact the potential problems are so numerous, that the Royal Commission itself, does not appear to want to address these issues. Once again the rights of urban Aboriginal peoples are being ignored.

It should also be noted, that the Native Council of Canada (now Congress of Aboriginal People) had attended annual intergovernmental meetings between the federal and provincial governments, with the intent of discussing Aboriginal selfgovernment negotiations. They met with only limited success in their lobbying efforts. Their attempts to establish ongoing intergovernmental relationships were put on hold during the constitutional process. They have this to say about intergovernmental relations:

Over the past decade, all structured discussions on Aboriginal matters at the intergovernmental level have been constitutional. Yet it is unlikely that a constitutional process respecting Aboriginal matters, or any other, will emerge within the next few years. (It is noted, however, that the timing of the release of the Royal Commission. recommendations in 1995 and the provision for a FMC on the amending formula by April of 1997 would suggest that such a process may well emerge in some fashion within two to four years.) ${ }^{34}$

They also comment that the participation of Aboriginal leaders in inter-governmental discussions on policies directly affecting them has been unquestioned. Yet there is no clear protocol respecting Aboriginal participation in these meetings. They note that without exception, provincial ministries dealing specifically with Aboriginal affairs have been set up in the provinces. 
In view of the complexity of jurisdictional issues that would have emerged from the Charlottetown Accord, it is easy to see why urban Aboriginal peoples might not have the same options and equal opportunity to become self-governing since they do not have an identifiable land base. Even though the Accord was never approved, it would have been a good idea for urban Aboriginal peoples to have some public discussions on the issue of guaranteed participation and representation in the Canadian political system, since this may be the only option open to them in the future. It should also be taken into consideration that, Aboriginal peoples living in urban areas may want to have their own governments, rather than just participation in the Canadian political system. Some may want maintain their direct ties with the community of origin, and have their rights protected in that community. If urban Aborigi, 1 peoples feel that they want greater participation in the Canadian political system, rather than their own system of governance, then they should at least be given the opportunity to discuss these issues in a community forum. 
This section will examine the current relationship of Aboriginal governments to urban Aboriginal peoples in regard to representation and accountability. It will also look at the application of Aboriginal governance in an urban setting.

Although many Aboriginal political organizations claim to represent Aboriginal peoples living in urban areas, this representation is fragmentary at best.

The structural problems, as many participants state, are obvious... Mostly, though, there is a jurisdictional void; all levels of government offload their responsibilities to Aboriginal urban people upon other levels of government. Participants felt that all governments, including Aboriginal governments, deny their obligations to Aboriginal urban people.

since the "band council" system under the Indian Act is the only legally recognized form of Aboriginal government, it will be necessary to include a discussion of the treatment of those individuals who are not resident in their communities, since this generally reflects government policy. The relationship between First Nations governments (band council system) and urban Aboriginal peoples is virtually non-existent. Although some First Nations do assume responsibility for the provision of certain forms of funding, such as post-secondary education assistance, to their members who are resident outside of their community, this situation varies from community to community. However, they usually do not provide services for those individuals who live outside of their communities. The 
program guidelines for post-secondary education funding makes specific provisions for etudents who matt live outside of their community in order to obtain an education. However, this is a deviation from the usual policy of the federal government in not providing services for those individuals who are not on-reserve. In particular, federal government policy in relation to urban Aboriginal peoples is usually to off-load their responsibilities to the provinces, and to 1 imit their responsibilities to a minimum.

In their report Aboriginal Peoples in Urban Areas, the Royal Commission very succinctly makes a number of points on the problems concerning representation and accountability:

Several other intervenors objected to offreserve band members being excluded from voting in band council elections. Bill Swimmer, a member of the Sweetgrass Band, noted at North Battleford, Saskatchewan, that 35 per cent of the band membership lived on reserve, and only half that number turned out to vote for the chief and council.

At Wendake, Quebec, Henri Trudel made the same point. Non-residents were barred from taking part in band decisions because of Article 74 of the Indian Act. As a consequence, the present council represented only 13 per cent of the membership of the band. He recommended a system of proportional representation based on family groups to ensure the widest possible participation in band government.

Another intervenor at Wendake, Michel GrosLouis of the Akiawenrak Long House, noted the different approaches of band councils and of traditional councils based on the clan and the long house. He proposed that in future negotiations with the federal government, the traditional council and band council should sit as equals."

Although they deal mostly with problems of accountability and representation concerning the application of the Indian Act, 
they reflect the 1 imitations imposed by government policy toward the exercise of Aboriginal rights in general, and limitations on the rights of urban Aboriginal peoples in particular. The Indian Act invites abuses in regard to unequal treatment based on residence, and the government tends to turn a blind toward these abuses so long as it works in their favour, by limiting their fiscal and/or their legal responsibilities to urban Aboriginal peoples.

According to a report on urban Aboriginal peoples by the Royal Commission, urban Aboriginal peoples feel that there is a lack of both representation and accountability in all levels of government, including the existing Aboriginal ones. As a result of this situation, they stressed that any urban Aboriginal government that was established had to be accountable to the people and representative of them.

Political organizations, whether they are territorially-based or uniquely urban, must be responsive and responsible to Aboriginal urban people. They said this might mean changing existing Aboriginal political organizations to include urban Aboriginal people. It might mean the establishment of new, strictly urban, Aboriginal organizations. But the arrangement had to be answerable to or controlled by Aboriginal urban people."

Not only do Aboriginal peoples want their government to be accountable to the community, but they also want it to be representative. They also want to be able to choose which organizations will represent them politically in order to ensure both accountability and representation. 
Some participante said it bolls down to a question of "delf-identification". Aboriginal urban people should have the freedom to choose which group they belong to and, therefore, which organization would represent them politicaliy. In this way, everybody could retain ties to their particular home community, retain their treaty or Aboriginal rights and strengthen their cultural identity. Aboriginal rights and identity would then be "portable", maintained and not undermined."

In one of their information releases entitled partners in Confederation, the Royal Commission on Aboriginal Peoples, came to the conclusion that there is no one model, or form of Aboriginal government that would be appropriate for all Aboriginal peoples. The Commission suggests that there are many ways of achieving greater control and autonomy for Aboriginal peoples, and that Aboriginal peoples should not be limited to one method or model of Aboriginal government.

Therefore, it appears that Aboriginal people are free to choose their own form of government, but the Royal Commission suggests that there are certain principles and guidelines that should be followed in order to achieve their goals. They also state that it would be a better idea to negotiate agreements with the federal and provincial governments, rather than trying to implement the right unilaterally. 


\section{Citirenghid: Problens with Defining Rights}

Aboriginal peoples claim the right to selfdetermination. Sovereignty is an integral part of the righte they claim under self-determination. What degree of sovereignty they require to exercise their rights to selfdetermination, is a matter that is still being debated. The claim to sovereignty does not mean the same thing to Aboriginal peoples as it does for instance; in Quebec where some people want to separate from Canada, and are already part of the Canadian state by virtue of their entering into Confederation in 1867. Aboriginal groups claim that they were not a party to Confederation, and as a result of this fact they were never part of the Canadian union. Not having been a party to the agreement signed at Confederation, they insist that they sill retain their original citizenship rights as Aboriginal peoples. Aboriginal peoples assert that they have Aboriginal citizenship rights that pre-date the establishment of the Canadian state. In Pathways to Self-Determination, Leroy Little Bear discusses his perspective on Aboriginal self-determination.

Indian leaders lay claim to sovereignty and nationhood for their people. Their conception of sovereignty and nationhood, with some variations, usually includes ideas of self-government, autonomous institutions, a territorial land base, and a resource base so that they can maintain the integrity of their culture and society... They point out that this right is a right that pre-dates the Canadian government; thus, the Canadian government was never in. a position to create or grant Indian self-government but merely to acknowledge it." 
Although this section deals mainly with the rights of Aboriginal First Nations, the concepts and principles can be applied to other Aboriginal groups, since they have been similarly affected by discriminatory government policies in regard to their rights to self-government.

The Canadian government's position is quite different. It holds that Indians possess and can exercise only those powers that are bestowed on them by Parliament. In the Canadian government's view Indians are subject to the laws of Canada, and their right to self-government, if any, is a delegated and limited privilege. This position has been upheld in judicial decisions by Canadian courts. The concept of a sovereign Indian nation is anathema to the Canadian government, which has uniformly insisted on limiting any negotiations on Indian government to discussions of increased band-level administrative powers on Indian reserves. This is to be achieved through a devolution of powers from the minister of Indian Affairs to the elected band council, but with ultimate control continuing to be vested in the Canadian government. ${ }^{40}$

The Canadian government(s) position has not changed significantly since this book was published in 1984. The government is still focusing mainly on self-government for First Nations bands with a land base, as oppused to urban Aboriginal self-government. Even though the Canadian government was willing to recognize the "inherent right" of Aboriginal peoples to self-government in the Charlottetown Accord, it appears that this right would have been severely limited in urban areas. Self-government in urban areas would have meant greater and guaranteed participation in the Canadian political system, rather than any form of urban Aboriginal government. Many Aboriginal groups living in urban areas assumed that they would be similarly entitled to their own governments regardless of where they lived. It appears 
that this would not have been the case with the Charlottetown Accord, since greater participation in the Canadian political system was being proposed, rather than any form of Aboriginal governance. Leroy little Bear discusses government policy in relation to Indian peoples, but this policy is equally applicable to all Aboriginal peoples:

The objective of Canada's Indian policy from the beginning was to "civilize" (meaning "assimilate") and integrate Indians, by degrees, into Canadian social, economic, and political structures. Traditional tribal government was seen as an obstacle to this process of civilization and integration. Thus, Canadian Indian policy called for the elimination of all vestiges of indigenous political institutions. One of the Canadian government's initial steps upon assuming responsibility for Indian affairs from the British was to replace traditional tribal political institutions with so-called "democratic" elective systems. This was done to prepare Indians for municipal types of institutions, like those of other Canadians. It was contemplated that the elected band councils would ultimately "graduate" to the level of exercising the same powers as municipal councils. Thus, the Canadian government would achieve greater control over Indians, and, at the same time, Indians would become part and parcel of the Canadian political system."

Under the Charlottetown Accord, Aboriginal peoples living in urban areas who were not part of a national Aboriginal political organization would have been given only one option in relation to self-government. That option would have been guaranteed participation in the Canadian political system, which has been one of the long term goals of assimilation. Urban Aboriginal people may not have had a choice in the matter, as to setting up their own institutions, they may well have been forced to participate in the Canadian political 
system regardless of any objeciions they may have had with the terms of the Charlottetown Accord.

In regard to citizenship rights, arising from the inherent right to self-government, Leroy Little Bear oaid this:
Although Canadian governments and courts have consistently ruled that Indians are subordinate to Parliament, Indian claims to nationhood and sovereignty have historical and moral justification. At the time of first European contact they existed as independent, self-governing nations or tribes: they exercised effective control over geographical areas: and they traded and made war with other nations. Indian leaders point out that their forefathers never surrendered their nationhood or right to self-government, nor was it taken from them by conquest. They claim that thpse rights were usurped surreptitiously by successive British and Canadian governments, in contravention of international law. The refusal by the Canadian government, until recently, to grant Indians full rights of Canadian citizenship is interpreted by Indians as clear evidence that Indians held another kind of citizenship."

The proposition that Indian peoples held other citizenship rights is also supported by the fact, that Indian people did not receive the right to vote in Canadian elections until 1960. If Aboriginal peoples were truly considered to be Canadian citizens, and had no right to self-government, then they would have had the right to vote in Canadian elections. Under the provisions of the Indian Act, if Indian people wanted to vote in Canadian elections, they had to give up their Aboriginal rights. This implies that Aboriginal peoples possessed other citizenship rights. In fact, many Aboriginal peoples believe that they have two sets of citizenship rights, one that they get from thoir historical Aboriginal rights and 
the other that they receive from the Canadian government. The problem is that they don't want to be forced to give up their Aboriginal citizenship rights. They not only have dual citizenship rights in Canada, but also are entitled to citizenship rights in " he United States. Some of these rights are mentioned in the Jay Treaty of 1794. The United States also recognizes the rights of Aboriginal people who come from Canada, by allowing them to live and travel in that country.

Possessing dual citizenship rights, and other overlapping rights does not present a problem to Aboriginal peoples, except when they are denied by the Canadian government. If Aboriginal people have the right to self-determination, and by implication self-government, then they in fact have dual citizenship rights. However, these rights have been defined as Aboriginal and treaty rights by the Canadian government and have been severely restricted. There are some problems with these definitions which arise from the application of the Indian Act, the territorial divisions created by the reservation system under the Indian Act, and the limitations placed on the traditional rights of Aboriginal peoples. There is a need to clarify amongst Aboriginal peoples just what their rights entail, whether they are enumerated and protected in a treaty, or are based on custom, or recognized in legislation such as the Indian Act. These rights are not uniformly applicable to all Aboriginal peoples, but certainiy there are underlying principles that should be observed. 
whether or not Aboriginal groups, such as First Nations, have "membership:" or "citizenship" rights is a matter of debate. If they are "nations", then it would be reasonable to assume that they are "citizens" rather than "members", because "membership" is something that is conferred on First Nations peoples under the Indian Act. Under the Indian Act, Aboriginal peoples became "members" of "bands", thereby undermining their Aboriginal citizenship rights. The imposition of the "band council" system under the Indian Act has obscured and limited the citizenship rights of Aboriginal peoples. The purpose of this system was to undermine their traditional political institutions, and to prepare Aboriginal peopl-s for assimilation into Canadian society. However, it did not take into account that Aboriginal peoples might not want to be assimilated.

It should be noted, that the Indian Act is an amalgamation of various pieces of colonial Indian legislation and provincial policies around the time of Confederation. This legislation had conflicting goals, and as a result of these conflicts, the Indian Ac- alternates between assimilation and protectionism. In particular, the policy of assimilation has resulted in differing legal status between various groups of Aboriginal peoples and a denial of their rights. The problems with this situation only become apparent, when the differences in treatment between Aboriginal groups cause frictions between them and/or the individuals affected by the policies. Ultimately the goal of assimilation 
is the elimination of Aboriginal Nations and their rights. Within the context of assimilation, the Indian Act could be viewed as restricting and regulating the rights of Aboriginal peoples. The desired result being a reduction in the number of Aboriginal peoples and by the same token, a reduction in the legal obligations of the government. The imposition of the Indian Act has undermined the rights of Aboriginal peoples to self-determination. It has extensively restricted and regulated their Aboriginal rights to the point where they are unable to exercise them outside of their limited land base. The Canadian courts have also played a significant role in defining and restricting the exercise of their Aboriginal rights, including "citizenship /membership" rights. In addressing the issue of Aboriginal self-government, the Royal Commission on Aboriginal Peoples has proposed, that although the Indian Act and government policy have restricted the rights of Aboriginal peoples, they still possess those rights.

The decision of the supreme court in the Sparrow case laid down broad guidelines governing the scope and effect of section $35(1)$, guidelines that will no doubt be clarified by the court over the next several decades. Thus far, it is clear that the section gives constitutional protection to a range of special rights enjoyed by Aboriginal peoples, shielding these rights from the adverse effects of legislation and other governmental acts... The Supreme Court held in the Sparrow case that if a right had been completely extinguished before 1982 , when section $35(1)$ was enacted, it could not be an "existing" right under the section. However, in the Court's view, an Aboriginal or treaty right that had merely been regulated by legislation did not cease to exist, even if the right had been confined to a very narrow compass. So long as the right survived in some form, however, slight, it qualified as an "existing" right under the section and recelved constitutional protection." 
If this same reasoning can be applied to Indian Act legislation, then the argument could be made that, although the government restricted and controlled Aboriginal "citizenship" rights by calling them "membership" rights, Aboriginal people are still entitled to the full exercise of these rights. In fact the Royal Commission makes the connection between "membership" rights and "citizenship" rights later in their report:

So, the phrase "Aboriginal peoples" in section 35 does not refer to groups characterized by their racia: make-up. Rather, it designates historically defined political units, which often have mixed compositions and include individuals of varied racial origins. Of course, just as the people of the province of Quebec are predominantly French in extraction and those in the province of Nova Scotia predominantly British, most members of Aboriginal nations trace their lineage in whole or part to precontact America. However, just as people of Irish, Italian, or other origins are Quebecers and people of Chinese or African descent are Nova Scotians, there is no reason why a person of Huron or French ancestry cannot be a full-fledged member of the Five Nations. The question of whether individuals qualify for membership in an Aborisinal group depends not on their racial origins, but on the group's rules concerning citizenship. This question, like any other question of citizenship, can turn on a variety of factors, such as parentage, continuing affiliation, self-identification, adoptive status, residence, and so on. In our view however, it cannot legitimately depend on genetic characteristics as such."

Following this interpretation of the Spacrow case, it would be reasonable to assume that even if Aboriginal "citizenship" rights are defined in a severely restricted form as "membership" rights under the Indian Act, that these rights still exist. They further state that their interpretation of the Sparrow case would similarly apply to the rights of Inuit 
and Metis peoples under section $35(1) .4$ The problems occur when one examines the rights and benefits which flow from "band membership" and realize that, at this point in time, the Canadian government controls who is entitled to membership/citizenship rights under the Indian Act. Therefore, the Indian Act deprives Aboriginal peoples of the full exercise of their rights to self-determination, including their "citizenship" rights.

In regard to the question of what type of citizenship rights of urban Aboriginal peoples would have under selfgovernment, Professor Brad Morse gave this view:

So long as the Aboriginal governments operate within the context of the Canadian state, Aboriginal peoples will be Canadian citizens - the question is, do Aboriginal governments want to have their own citizenship (as opposed to membership) laws such that their citizens would be dual citizens? But in the urban context the question is more complex as is the single nation. Si if citizenship applies it would be as citizens of the newly created urban government. Would the latter recognize retaining citizenship in the person's original nation or require relinquishing it (e.g., Canadian, Haida and Vancouver Aboriginal government citizen, or give up Haida to vancouver Aboriginal government citizenship?) If not recognized as a citizen of the urban Aboriginal government, $t$..an presumably the person would have no relationship with that Aboriginal government -- Alternatively people would not be "citizens" of the Aboriginal government but merely residents and electors as opposed to residents of Ottawa, who are not citizens of Ottawa. There is invariably an appeal process regarding decisions on citizenship."

It is obvious, from his commentary that there are a wide range of rights that Canadians exercise, including citizenship rights. Many of these rights are based on residency, and will 
affect the ways in which Aboriginal peoples might be able to exercise their citizenship rights under an urban Aboriginal government. The type of government envisioned by urban Aboriginal peoples might resemble a municipal form of government, but would not necessarily exercise the same powers. However, this is a question that Aboriginal people who are living in urban areas need to discuss, and must decide for themselves.

Although the views of the Royal Commission, on Aboriginal citizenship rights may be seen as much more positive for Aboriginal peoples, there is no guarantee that the government of the day will accept them. In addition, although the views of the Commission may be more liberal, they certainly don't meet the expectations of Aboriginal peoples in regard to their rights to self-determination. However, any methods that the Royal Commission can utilize to ensure that these Aboriginal citizenship/membership rights are more fully recognized would be a step in the right direction. 


\section{J'yrisdiction Iseves}

At the present time, there are a number of jurisdictional problems which affect Aboriginal peoples living in urban areas, and these problems will impact on the way in which self-government could be implemented. Some of these problems are due to differences in the legal status and treatment of the various Aboriginal groups, while others are jurisdictional disputes with other levels of government, specifically in implementing urban self-government. The resolution of these problems will have a direct impact on the rights that these Aboriginal peoples will be able to exercise under any urban governance arrangements and/or negotiations on such issues.

Clearly, there is a need to examine some of the more important problems that affect urban Aboriginal peoples in relation to jurisdictional issues. The following discussion will give a general overview of these problems, and outline some options that could be pursued.

The federal government would probably like to avoid dealing with the issue of how the right to self-government would be applied in urban areas. They try to rationalize their position by arguing that there are too many problems to sort out concerning jurisdictional disputes. The Royal Commission states in their publicatior entitled, Partners in Confederation, that "the case of Aboriginal groups without any form of land base is different and poses a range of 
complex questions that cannot be dealt with here"." This statement is consistent with past government policy of dealing only with Aboriginal peoples living on identifiable land bases, ie. bands under the Indian Act. The legal distinctions which the government created through the Indian Act would remain in place, and would maintain the inequalities that already exist. In the present situation, Aboriginal people who live in urban areas are unable to most of the programs and services which are available to Aboriginal peoples living on reserves, and are treated differently. Government policy towards Aboriginal peoples living in urban areas has been to deny them the exercise of their rights through policies of assimilation. In fact, government policy has encouraged assimilation through participation in their governmental structures, and the Charlottetown Accord represented yet another attempt to assimilate Aboriginal peoples into the Canadian mainstream. Although the Accord offered Aboriginal peoples a greater opportunity to address their some of their problems, it was still not the recognition of their rights that Aboriginal peoples had envisioned. In fact, many Aboriginal groups felt that the Accord didn't go far enough in recognizing theix rights to self-government. While the potential benefits of participation in the Canadian political system may have been enticing, many Aboriginal people saw this type of participation as one more step toward assimilation and would not support it. During this time there were numerous debates and political wrangles between the various organizations representing Aboriginal peoples, particularly 
those organizations which claimed to represent Aboriginal peoples living in urban areas. Many of these problems were a result of the differences in legal status and unequal treatment of Aboriginal groups, and discriminatory government policies. Because of these problems, Aboriginal peoples living in urban areas might not be afforded the same opportunities to achieve self-government, as those peoples who have an identifiable land base. The government simply cannot ignore its responsibility to urban Abnriginal peoples to ensi e that they have an equal opportunity to secure their rights to self-determination/self-government.

While urban Aboriginal peoples possess the inherent right to self-determination/self-government, they are likely to experience more difficulties in implementing it, than are other Aboriginal groups. Some problems are due to their cultural, social, and political diversity, others are structural, and still others are practical administrative matters which need to be addressed.

Because of various jurisdictional disputes, both current and potential, it is clear that a transition period will be required in order to implement urban self-government. This transition period may well take longer in urban areas. Because Aboriginal peoples live in urban areas where they have been governed by federal, provincial, and municipal jurisdictions, urban Aboriginal peoples will have more problems in establishing their governments, and in determining 
their jurisdictional responsibilities, including negotiating Iimits with other governments.

Implementing self-government in urban areas will cause some difficulties, precisely because urban Aboriginal people do not have an identifiable land base. As a result of this, they face different problems than those Aboriginal groups who occupy specific territories. These differences must be taken into account when looking at the issues involved in protecting the rights of Aboriginal peoples living in urban areas. This situation can be problematic, because many of the rights that Aboriginal peoples exercise are land based rights, and have been limited to their traditional territories through government policy. Therefore, accommodating these differences might be difficult, but they must be taken into consideration.

The differences between the rights that various Aboriginal peoples have been able to exercise, and their connection to a land base are recognized by the Royal Commission, however, they also were at a loss to deal with the protection of these rights in urban areas. In a publication entitled, Partners in Confederation, the Royal Commission set out some standards and "two pre-conditions", that Aboriginal peoples should be met before they can implement self-government. However, they cannot guarantee that these standurds will be adopted by government, therefore urban Aboriginal peoples might be required to meet additional criteria in order to considered eligible to negotiate self- 
government arrangements. At the same time, these views are consistent with past government policies based on assimilation, which created discriminatory legal distinctions between various groups of Aboriginal peoples.

An Aboriginal group that has a constitution and a reasonably definite membership is in a position to exercise its right of self-government, within the core areas of Aboriginal jurisdiction. If it wishes, a group may do this in an incremental way, gradually assuming control over a range of matters previousiy administered by other governments, in a manner and at a speed dictated by community needs and priorities."

At various times, these inequalities have been challenged by Aboriginal groups in the international arena, and are inconsistent with charter rights, and basic human rights legislation in Canada. Faced with many pressures to change this situation, the Canadian government has made some changes in their policies, but they have not addressed many key issues in attempting to deal with these equalities it created.

The Royal Commission is also of the opinion that while a transition period may be required, this should not serve as an excuse to post-pone the implementation of Aboriginal selfgovernment indefinitely. Whether, or not, federal and/or provincial governments support the Royal Commission's enlightened views on Aboriginal self-determination will be another matter altogether. However, this should not be taken to mean that their opinions should be ignored. Their views do represent a more liberal interpretation of Aboriginal rights in general, and self-government in particular. 
There are a number of existing jurisdictional problems that should be clarified and addressed in order to implement Aboriginal self-determination/self-government in urban areas. There are problems with the relationships, and/or lack thereof, between various Aboriginal sroups, service organizations, and political representatives and lobby groups. Many Aboriginal peoples living in urban areas feel that they are not adequately represented within national Aboriginal political organizations.

At the same time, Aboriginal organizations claim to represent Aboriginal urban people but involve little accountability and almost no voice for Aboriginal urban people. For instance, many programs apply only to on-reserve status or Treaty Indians and are not extended to off-reserve Indians. Similarly, Metis and non-status groups receive funding for services in urban areas but deny that service to status or Treaty Indians. In other words, participants said, each Aboriginal organization practises its own form of discrimination, with respect to the Aboriginal urban population.

At the same time, there are other problems which are administrative in nature and have to do with the responsibility and capability of existing Aboriginal governments to deliver programs and services to their people who live in urban areas, which must be examined. There are many questions that need to be answered as to whether or not Aboriginal peoples living in urban areas want their own form of government, and what the structure and rowers of that government would entail. The rasolution of these issues are critical for Aboriginal peoples living in urban areas. They 
need the opportunity to discuss amongst themselves, how they would implement self-government, and what areas they would want jurisdiction over. Although some of these issues were dealt with in the Charlottetown Accord, they are still problematic because of its failure. Urban Aboriginal peoples need to discuss furisdictional issues and more, so that they will succeed in their endeavour to implement self-government.

More general aspects of the jurisdictional problems which affect urban Aboriginal peoples were identified during the round table discussions on urban issues, held by the Royal Commission. Aboriginal peoples indicated that jurisdictional disputes are a major problem:

Participants routinely identified jurisdictional problems in every area of discussion, whether it was economic development, health or services. These problems, they said, stem from the way federal legislation divides Aboriginal people into different categories with different rights. These same laws further divide a single Aboriginal group into several other categories, again with differing rights attached. For instance, these laws imposed different regimes on status or treaty Indians and on non-status or Bill C-31 Indians.

Jurisdictional disputes between the federal and provincial governments are also commonplace, and lead to off-loading in terms of responsibility for Aboriginal peoples living in urban areas. More often than not, they found that they were in a jurisdictional vacuum with netther level of government willing to address their problems. There are many Aboriginal peoples, whether individuals, or groups, who are not receiving the programs, benefits, and services they need and should be entitled to receive. These problems are due in large part to 
what Aboriginal peoples view as discriminatory government policicu. In the round table discussions on urban issues, the Royal Commission reported that:

Furthermore, participants said, governments have established sometimes stark and ill-defined 1 ines of jurisdiction over certain Aboriginal groups but excluded other groups. For example, the federal government has jurisdiction for First Nations people on-reserve but denies responsibility for status or treaty Indiens off-reserve. The provincial government says urban status Indians are $i$ federal responsibility, yet it applies its laws on reserve. Participants said these legal definitions when combined with confusing and conflicting lines of jurisdiction, create a jurisdictional void when it comes to Aboriginal urban people."

Based on this commentary, it is easy to understand the confusion concerning the ways in which the federal and provincial governments claim and exercise jurisdiction over Aboriginal peoples. The problems arise when they don't fulfil the responsibilities that go along with the jurisdiction. Aboriginal people want clearer lines of responsibility in terms of governmental jurisdiction, whatever level of government assumes jurisdiction over them. Unfortunatel" in the present situation, it has worked in the government's favour to blur those lines of jurisdiction, and to deny responsibility in many areas.

One of the government's main goals has been to divest itself of any financial and legal obligations to Aboriginal people wherever possible. In the long term, this has meant reducing the number of Aboriginal people who have legal status, and therefore qualify for the orograms and services they offer. The fewer Aboriginal people they have to provide 


$$
2 \text { oflde } 2
$$


programs and services for, the easier it will be to justify eliminating these programs and services completely. The legal distinctions that the government created between the various groups of Aboriginal peoples have already reduced the government's legal and financial responsibilities.

It has worked to the government's advantage when Aboriginal peoples move into urban areas, for whatever reason. The government will assume only limited responsibility for delivery of programs and services for Aboriginal peoples who do not live on reserves. The Department of Indian Affairs and Northern Development (DIAND), which has responsibility for the delivery of programs and services to Aboriginal peoples discriminates between on-reserve and off-reserve Aboriginal peoples. They claim responsibility for only those Aboriginal peoples who live on-reserve. Therefore, the Aboriginal peoples who receive the largest amount of benefits are usually those who live on reserves. Taking into consideration that nearly three-quarters of the Aboriginal population lives ir urban areas, this policy works to reduce the number of Aboriginal people it has to service. And where it cannot reduce the number of people, it reduces the amount of funding it expends on the various groups.

They are not well served. Jurisdictional wrangling between the federal and provincial governments is the main culprit. Neither level of government is anxious to take responsibility. Social service programs with unclear mandates are hampered by unstable or inadequate funding, and many Aboriginal people fall through the cracks of government programs. 12 
The impact of the government denying and/or limiting its responsibilities for Aboriginal peoples living in urban areas has a serious impact on that population. During the round table discussions on urban issues, held by the Royal Commission, Aboriginal people identified the need to provide equal and universal access to programs and services for Aboriginal people living in urban areas, regardless of their legal status.

A majority of participants agreed on the need for status-blind service centres in major cities across Canada. The question of which existing Aboriginal organization would administer these centres was not resolved. However, participants did agree on certain points that might make the establishment of these service centres possible.

The institution would have to be established along principles that are kboriginal in nature - it should not be merely a clone of non-Aboriginal institutions. There are few examples of such institutions at present, however.

There was agreement, however, that the service centres and their administration would have to be responsive to the needs and accountable to the Aboriginal urban population. Since the Aboriginal urban population is diverse, if not divided, participants proposed the creation of service boards with representation from the various groups within the Aboriginal urban population and possibly reserve and settlement Indian and Metis representation as well.

The organization should provide a unified status blind voice and eliminate unnecessary duplication of services. It uhould be a political body representing both grassroots people and service organizations. Such a body would need real power in order to be effective. One working example, the United Native Nations in Vancouver, has served as a model for the Native Council of Canada. A similar mulel in Regina was relatively unsuccessful due to political disagreements. 
Because Aboriginal people view self-government from a holistic perspective, their concepts of government structure, powers, and jurisdictions are integrative. They see their governments as dealing with a variety of issues, while serving as a coordinating body that is accountable and representative of the Aboriginal people they serve. Because Aboriginal political organizations and urban Aboriginal organizations involved in service delivery are not accountable to each other, they have had very little direct contact especially in urban areas. Since separate organizations also exist that service Aboriginal peoples with different legal "status", their relationships are very fractured, even though they may be involved in delivering similar services.

Until recently, government services aimed at urban Aboriginal people concentrated on integrating them into the general population. However. friendship centres - which are among the few urban Aboriginal service delivery agencies view their role as countering this push toward cultural assimilation and shouldering more responsibility for the welfare of the urban Aboriginal population."

Friendship Centres are just one example of existing organizations which are concerned about the ways they will be affected by self-goverument arrangemants, and who also want greater control over the programs and services they deliver. In some ways. Friendship Centres function as comnunity centres and social service agencies, but they go beyond simply being a referral service, or gathering place. Friendship Centres suffer from the same problems of other urban Aboriginal service organizations because they have no effective means of influencing political organizations on issues of concern to 
urban Aboriginal people. They service and represent the interests of a large segment of the urban Aboriginal population, but they are not an Aboriginal political organization.

Despite the presence of friendship centres in many urban centres, urban Aboriginal people continue to lack political representation and organization. While some would like to see friendship centres become a political organization representing urban Aboriginal people, the strong loyalties of many Aboriginal people to their own communities and cultural groups make it unlikely. In fact, any sort of co-operative urban Aboriginal movement has been hamstrung by scarce resources, fragmented populations, unclear mandates, and a lack of Aboriginal, federal or provincial encouragement and support.

Friendship Centres are much more than just a service delivery agency, in fact they serve a number of functions in the urban Aboriginal community. They have evolved into multi-service organizations in urban areas. This type of evolution is consistent with the holistic approach that Aboriginal people utilize when dealing with issues that affect the urban Aboriginal community. Although Friendship Centres carry out administrative responsibilities in relation to the programs and services they offer, they tend to fill the jurisdictional void. They do this through assisting in the development of other service organizations, and/or programs and services. They can't do an effective job filling the void with their Iimited financial resources, but they do provide us with a model for service delivery in urban areas. In the public hearings held by the Royal Comission, Friendehip Centres were seen as potentially playing a central role in the delivery of services to urban Aboriginal peoples under self-government. 
Many participants saw an expanded role for friendship centres in establishing this structure of service delivery. Friendship centres are already status-blind and do much of the work already. Why can't they play a central role in guiding the establishment of these service centres, one participant wondered.

They were used as an example of an organization that delivered services to urban Aboriginal people without regard to their "status", which was seen as mostly positive. But the question as what role the Friendship Centres will play under urban Aboriginal government has yet to be determined. This is an issue that is in need of further discussion not only among the Friendship Centres, but between the Aboriginal political organizations, and other Aboriginal organizations involved in urban service delivery. 
In considering the constitutional process, the Royal Commission, argues that Aboriginal self-government is already protected in section 35 of the Constitution Act, 1982:

Section 35(1) of the Constitution Act, 1982 guarantees the existing Aboriginal and treaty rights of the Aboriginal peoples of Canada. As the paper explains, there are persuasive grounds for believing that this provision includes an inherent right of self-government. This view has significant implications for Aboriginal peoples, for federal and provincial governments, and for the public at large. It therefore merits wide public discussion. 37

They go on to discuss their views that, although the inherent right to self-government was a point of constitutional negotiation in the Charlottetown Accord, all the clause did was to "recognize" that the right already existed, it did not create the right.

Over the following decade, the goal of further constitutional reform was actively pursued. Several intensive rounds of constitutional negotiations took place between Aboriginal peoples and the federal and provincial governments. One major aim was to secure explicit constitutional recognition of the right of self-government. These efforts culminated in the detailed Aboriginal amendment proposed in the Charlottetown Accord of 1992 . Despite the complexity of these provisions, one simple clause lay at their core; it stated that the Aboriginal peoples of Canada had the inherent right of selfgovernment within Canada."

In an article that appeared in the Globe and Mail, on September 7, 1993, Co-Chair of the Royal Commission Rene Dussault, reiterated that the Commission's view that the inherent right to self-government was one of the rights entrenched under section 35 , in 1982. He says that the "Charlottetown Accord would have made that fact explicit, but 
it would not have created the right; it would only have confirmed it"."s"

Under the terms of the Charlottetown Accord, the areas of jurisdiction that urban Aboriginal governments could control would have been the subject of negotiation. In fact, there are several areas that urban Aboriginal pcople have already asserted their control over. The level of control they have assumed varies according to the issues they feel are important to address.

By the same token, urban Aboriginal people need to define just how much local control they want and what issues they want to be negotiated. A process of negotiation will be required in light of all the potential areas of overlap. These negotiations will need to define the scope of the jurisdiction of urban Aboriginal governments. At the same time, the role of existing urban Aboriginal organizations which provide services to Aboriginal peoples in urban areas must be taken into account under any self-government arrangements.

Certainly those Aboriginal peoples with an identifiable land base will be in a better position to negotiate selfgovernment simply because it will be less contentious. But if governments are willing to negotiate with urban Aboriginal groups in regard to retaining jurisdiction in certain areas, Aboriginal peoples might be persuaded to accept certain limitations, in exchange for concessions in other areas. 
Although urban Aboriginal peoples may possess the inherent right to self-government, a reasonable pariod of time will be required during any transition to self-government. The Royal Commission report Partners in Confederation, suggests some guidelines for self-government neçotiations.

Nevertheless, Aboriginal peoples and their governments do not exist in isolation but as units within a complex federal system. So under our second guiding principle, it is desirable that selfgovernment be implemented with the co-operation of federal and provincial authorities, which should be ready to respond in a timely and appropriate fashion to the initiatives of Aboriginal peoples. This will require such authorities to put in place flexible mechanisms and procedures for facilitating the move to self-government. It will also necessitate some clarification of the respective roles of the federal and provincial governments in the process."0

These guidelines suggested that the cooperation of the federal and provincial governments should be sought. However, they also state that Aboriginal peoples should not have to wait for government approval before moving to implement their rights.

To sum up, it would generally be preferable for Aboriginal peoples to implement their inherent right of self-government by way of agreements with federal and provincial authorities, in the spirit of cooperative federalism, so that such important matters as jurisdiction, financing, and transitional arrangements can be handled in an orderly and amicable manner. However, in the final analysis there are persuasive reasons for thinking that in core areas Aboriginal peoples may implement their right to self-government at their own initiative, without the concurrence of federal and provincial authorities."

In the end, they conclude that Aboriginal people do not need the permission of the federal and provincial governments to implement their rights. These statements seem contradictory, and are reflective of the confusion and problems associated with understanding the concept of Aboriginal self-government. 
There is still a need on the part of the Canadian government, and Aboriginal groups to clarify some of the problems and issues associated with implementing Aboriginal self-government, erpecially in the urban context. There are still many conflicting views on how self-government could be implemented in urban areas. It appears that Aboriginal peoples living in urban areas still need to have public meetings to discuss and define the self-government amongst themselves. 


\subsection{Canadian Constitution Section 91.24}

In Partners in Confederation, the Royal Commission on Aboriginal Peoples attempts to deal with the problems of overlapping governmental jurisdictions and the idea that the jurisdictions of Aboriginal governments can be accommodated within the present constitutional framework. They discuss the arguments put forward by the federal and provincial governments that any governmental powers which were held by Aboriginal peoples were extinguished at the time of Confederation in 1867. The Constitution lists the powers of each level of government and their areas of jurisdiction. The Royal Commission suggests that although section 91(24) of the Constitution Act gives the federal government authority to deal with "Indians, and Lands reserved for the Indians", that these governmental powers are not exclusive.

Section 91.24 of the Constitution Act, 1867 assigns
legislative authority to Parliament for "Indians,
and Lands reserved for the Indians". This power has
been exercised principally through the Indian Act,
first enacted in 1876 and amended most recently in
1985. Although the federal government has exclusive
power to legislate with respect to Indians (and
Inuit, according to a 1939 Supreme Court
interpretation of section 91.24 ), provincial and
municipal governments have often introduced programs
that respond to the distinctive needs of citizens,
as they have done, for example, with respect to
immigrants. "2.

They conclude that although the federal government has exclusive power to legislate in this area, they are not the only body capable of doing so. They suggest that in practice, governments may have concurrent powers to legislate in areas of overlapping jurisdiction. 
As a matter of principle, the fact that a governmental body has the power to deal with a certain subject does not necessarily mean that it has exclusive powers, that it is the only body competent to deal with this subject. To the contrary, it is common for two or more governmental bodies to hold overlapping or "concurrent" powers. Such is the case, for example, with the federal Parliament and provincial legislatures in certain areas. Where bodies holding concurrent powers come into conflict, it is necessary to establish which body has priority in the area. In the absence of conflict, however, both bodies are free to deal with the area in question. So, for example, even if the federal government had extensive authority to deal with Indian affairs under section $91(24)$ of the 1867 Act, it was not necessarily the only body capable of dealing with these matters.

So, although the federal government has the final authority in this area, the provincial governments may also deal with these issues. However, if they did come into conflict the position of the federal government would have priority on the issues. 


\section{Metis Nation Accord}

The Metis Nation Accord was part of the provisions which for Aboriginal peoples which were included in the failed constitutional negotiations on the Charlottetown Accord. It might be a good idea to revisit these provisions in order to access not only where the provinces stood on the issue of Aboriginal self-government, but also serve as a guide to future development. This is especially true of the provisions of the Metis Nation Accord which promote greater Aboriginal participation in the governing institutions of Canada, which might serve as points of negotiation for urban Aboriginal people.

\section{Metis Nation Accord (*)}

The federal government, the provinces of Ontario, Manitoba, Saskatchewan, Alberta, British Columbia and the Metis National Council have agreed to enter into a legally binding, justiciable and enforceable accord on Metis Nation issues. Technical drafting of the Accord is being completed. The Accord sets out the obligations of the federal and provincial governments and the Metis Nation.

The Accord commits governments to negotiate: self-government agreements; lands and resources; the transfer of the portion of Aboriginal programs and services available to Metis; and cost-sharing arrangements relating to Metis institutions, programs and services.

Provinces and the federal government agree not to reduce existing expenditures on Metis and other Aboriginal people as a result of an amendment to Section 91(24). The Accord defines the Metis for the purposes of the Metis Nation Accord and commits government to enumerate and register the Metis Nation.

Section 56 of the Charlottetown Accord would also have given greater protection the lands of the Metis in Alberta. The Accord would also have offered much better protection for the 
rights of Aboriginal peoples in general, but would have extended some of these protections Aboriginal peoples living in urban areas. In general, it would also have committed the governments to assisting Aboriginal peoples in achieving selfgovernment.

The Metis Nation Accord was especially significant for urban Aboriginal peoples, because the government began preliminary self-government negotiations with several groups of Aboriginal peoples, who were not previously recognized as being entitled to self-government.

A proposed Political Accord drafted at the time of the Charlottetown Accord in 1992 provides a further example of a framework agreement, one the nevertheless remains unfulfilled. The document recites that the federal government, the provinces of Ontario, Manitoba, Saskatchewan, Alberta, and British Columbia, and the Metis National Council have agreed to enter into a Metis Nation Accord... Since the demise of the Charlottetown proposals, no further action has been taken on the Accord by the governments concerned.

Although the Metis Nation Accord was not implemented, it is an example of the various arrangements that could be made under Aboriginal self-government. It was also significant because recognized the rights of certain urban Aboriginal groups to enter into negotiations on their own behalf. The Metis Nation Accord serves as an example of a specific urban Aboriginal group that the government/s recognized as having the right to self-government.

3. The Metis Nation Accord requires Federal and Provincial governments to negotiate with MNC's and PTOs regarding Metis, the PTOs control membership, the PTOs will decide what Metis self-government will mean." 
It also set out areas of negotiation and recognized the rights of these organizations to negotiate self-government arrangements on their own behalf, and through an orderly process. 
Although most Aboriginal peoples living in urban areas may not want to assume jurisdiction over a particular land base, or natural resources, some groups such as the Metis want lands set aside for their own use. Many groups also want to expand their landbase because their communities are growing and they don't have enough lands available to accommodate their population. They may also need access to other lands in order to create economic self-sufficiency within their communities, so that they are not operating on welfare economies.

What most urban Aboriginal peoples do want, is jurisdiction over their own people, as opposed to a particular piece of land or territory. They also want to able to negotiate with governments for a share of revenues from natural resources, as opposed to having a legal and/or legislarive jurisdiction to regulate natural resurce development. Although some groups may want to participate in such areas, and therefore, their rights to negotiate on these issues should be recognized.

In general, Aboriginal peoples' belief that they are entitled to more land than they presently control, has generated conflict and fear on the part of non-Aboriginal peoples. Many are afraid of what this would mean to their current land holdings, there are those who fear a massive 
land grab, and those who are simply ignorant of history of Aboriginal land issues. Aboriginal peoples have a long list of grievances with the current land claims process, especially the length of time that it could take to resolve these issues. While most Aboriginal groups do want to negotiate land settlements, they do not usually cover urban areas. In addition to this, $t$ - current land claims process excludes Aboriginal peoples who live in urban areas, and usually provides for financial compensation in areas where the lands are otherwise occupied.

Some Aboriginal and treaty rights are tied to the traditional territories of a specific Aboriginal nation. while others rights and benefits are portable. Aboriginal lands rights and entitlements are not an easy subject to address, and how they may apply to urban Aboriginal peoples is even more difficult to discuss. Some Aboriginal peoples who do not have a specific land base, such as the lands set aside under the Indian Act, want to be able to negotiate for a land base. Some Aboriginal and treaty rights are derived from land surrenders in exchange for certain material goods, jurisdictions, or harvesting rights, and in many cases include financial compensation, which urban Aboriginal people may not have access to, or u' $y$ not be able to exercise in an urban area. Whatever the case, they want to retain their Aboriginal and treaty rights regardless of residence. Former National Chief of the Assembly of First Nations, Georges Erasmus, looks at the financial aspects of the land claims 
process in order to put the issue of compensation into perspective:

The evidence shows that since the rise of modern Indian political movement, governments have consistently underrated the seriousness of the claims for land, resources, and self-government that could be mounted by First Nations in all parts of Canada. So little attention was paid to these claims in the first half of this century that a cabinet docunent of the late 1960 's suggested the Canadian government could settle all Aboriginal land claims in the country for \$11 million. A more recent estimate has put the figure at $\$ 4.8$ billion. Though there is far more involved than money, the difference in the two figures is a measure of the unreality of the traditional response of Canadian society to Aboriginal claims. And it is, perhaps, an explanation of the panic that seems to seize contemporary Canadian politicians in face of our demand for just treatment."

Aboriginal peoples have Ownership of less than .05 percent of the land in Canada. Aboriginal peoples have laid claim to large portions of Canada, as part of the land claims process, in order to obtain compensation or the return of certain portions of land.

Although the reserve system was initially put in place to ensure the protection of the land base of Aboriginal peoples, it also served to remove them from large tracts of land for the purposes of white settlement. According to statistics from the Department of Indian Affairs and Northern Development, approximately 10,000 square miles of land have been set aside as reserves." These lands have a special status in Canadian law, and certain immunities along with it. In many cases, lands were taken from Aboriginal peoples under coercion and fraud by white settlers, and in other cases they 
were simply taken away by the federal and provincial governments without Aboriginal consent. Many Aboriginal peoples have experienced large scale dispossession of their traditional territories, and are trying to reclaim some of those lands. As a result of these government actions, Aboriginal people have many issues they would like to see addressed especially concerning jurisdiction over lands and land based rights.

In the case of urban Aboriginal peoples, most of the groups have not claimed a land base under self-government. However establishing that they are entitled to the right of self-government will be difficult, because historical occupation of an identifiable land base is one of the criteria used to determine eligibility to negotiate self-government arrangements. These criteria serve to restrict the exercise of Aboriginal self-government to reserves. Urban Aboriginal people who do not have a historical land base located in, or near, an urban area, will not meet these criteria. Therefore, either the restrictive criteria must be changed in order to guarantee equal access to the right of self-government for those Aboriginal peoples without a land base, or they will have to be given a land base. Obviously, changing the criteria to accommodate the aspirations of urban Aboriginal people in regard to self-government will be much easier to accomplish than engaging in negotiations to secure a land base. Especially since, their chances of succeeding in auch an endeavour are not very good. Urban Aboriginal peoples need 
to ensure that their rights to self-determination/selfgovernment are recognized by Aboriginal political organizations, First Nations, and other Aboriginal groups by making them aware of the issues that affect them. 
One of the more heated debates on Aboriginal selfdetermination/self-government, has been the cost of financing it. Aboriginal governments must have access to adequate financial resources. Both federal and provincial governments want to know where the funding will come from and how much it wi 11 cost.

Some of the questions not usually asked, are how much mone; is government spending right now? Why is the present system inadequate? And what can be done to change this situation? The Native Council of Canada, in their report on Fiscal Relations and Arrangements: Aboriginal Patterns, Trends and Answers, tries to give an accurate description of the existing fiscal expenditures for Aboriginal peoples and to offer viable solutions in financing Aboriginal selfgovernment.

5. It would be foolhardy to describe the vast differences in the way governments appropriate and spend $f$ isca! resources to meet Aboriginal needs or to meet their obligations to Aboriginal people and communities. It also would not shed light on the possible answers, because debate would then centre on the reasons for historical disputes - whether jurisdictional or legal - that have, more often than not, stifled and blocked progress... Jurisdictional and legal disputes are often perceived as the major stumbling blocks to making fiscal decisions and taking action. But they are neither unique or exclusive to Aboriginal fiscal issues." 
government a reality. In the current gituation, they have been impoverished and have little control over how funds are spent. The government provides only enough financial support to Aboriginal communities in order for them to survive. There are very few prosperous Aboriginal communities in Canada, and those that have some wealth are the exception to the rule. The Native Council of Canada has this to say about the financial expenditures being made on Aboriginal peoples by all levels of government:

The bulk of federal, provincial, and territorial expenditures towards Aboriginal peoples are earmarked for basic necessities, not wealth generating or developmental initiatives. These expenditures sustain welfare and dependency conditions, because they are mainly geared to income support, health, housing and capital works programs which never catch-up to the growing demand. It is not surprising the poverty conditions have changed little. Most of the economic and employment benefits of these expenditures flow to neighbouring non-Aboriginal communities with businesses relying on Aboriginal consumers."

Economic development must be a central concern of any Aboriginal self-government negotiations. To ignore the need for economic development in Aboriginal communities, will lead to failure in attaining an acceptable lerel of financial independence. This would condemn Aboriginal people to total financial dependence on government, and would maintain the status quo to the detriment of both the Aboriginal peoples and the governments they depend upon.

8. It is not possible to determine with precision the total provincial expenditures to meet Aboriginal needs especially those outside of reserves. This will take some research, but it is a necessary step to unravel fiscal issues and put them into a national perspective. 
9. Federal program spending, on the other hand, is known (see Annex A). It is estimated at $\$ 4.4$ billion in 1991-1992.

10. What is not well known is that federal spending - on a per capita basis - is now lower than in 1985-86, the first full year of the Progressive Conservative administration. The real dollar value has dropped to $\$ 6,390$ per capital for a shortfall of $\$ 725$ million in 1991-1992, taking into account inflation and registered Indian population growth ( see Annex B). This downward trend is expected to continue. "

There are a number of reasons that Aboriginal peoples want recognition of their rights to self-government, and not all of them are financial concerns. There are many additional human costs associated with the present situation for Aboriginal peoples. Such as, the high rates of social problems, poverty, and dependency associated with colonialism, and they are costs that Aboriginal people are no longer willing to pay. 


\subsection{Taration}

If any group has a right to complain about taxation problems, it is urban Aboriginal peoples. Urban Aboriginal peoples have no input into the government's fiscal policies, the way they are developed, or implemented. Urban Aboriginal people also have no formal representation, participation, and/or consultation with Aboriginal political organizations dealing with taxation issues directly affecting them. Not only are their interests not taken into consideration by the existing Aboriginal political organizations and governments, but they don't have a formal voice in non-Aboriginal governments either. The majority of Aboriginal people in urban areas pay both federal and provincial taxes, but they have no way of influencing how their tax dollars are spent.

While, federal and provincial taxes are paid by all Aboriginal people, the 3 out of 4 Aboriginal persons living outside reserves pay the most tax. An estimated $\$ 4$ to $\$ 4.5$ billion in taxes is paid by Aboriginal families living outside reserves. Interestingly, it is these Aboriginal families who pay for the costs of federal programs, yet receive little benefits from it. It is more than likely they are paying for the benefits and services received from governments. ${ }^{72}$

If the estimated $\$ 4.5$ billion in taxes that urban Aboriginal people pay, could be redirected to pay for urban Aboriginal government, the fiscal problems associated with implementing urban self-government could be solved.

There is a widespread misconception that Aboriginal peoples do not pay any taxes. While a small portion of 
Aboriginal people (30\%) living on reserves receive various tax exemptions, these exemptions are not available to 708 of the Aboriginal peoples who live in urban areas because they are based on residency. There is a long history of tax exemptions for Aboriginal peoples, due in part to exemptions incorporated under the Indian Act, land surrenders, terms of treaties, and general practices within the provinces.

Almost all Aboriginal peoples who live off-reserve pay taxes. This is a concern for them because many feel this is taxation without representation. In the end, what concerns them most is that they are unable to determine where those monies that they generate will be spent. Although Aboriginal governments may receive funding from the federal government for the various programs and services they deliver, they are still bound by the guidelines and control mechanisms built into the terms of the agreements. Therefore their ability to determine where and how they will expend these funds is severely limited.

Fiscal transfers to Aboriginal governments and institutions have not changed very much since the 1960's. They vary extensively. Most are conditional transfers requiring considerable administrative costs. Financing mechanisms include: loans, loan guarantees, grants, repayable and nonrepayable contributions, :tatutory payments, and fee-for-service contracts. Very few are based on a government-to-government relationship or negotiations. ${ }^{73}$

In addition to this, the majority of funds expended on Aboriginal programs and services are earmarked for those Aboriginal peoples who live on reserves. There is a need to 
address this situation, since 738 of the Aboriginal population does not live on reserves.

It is because the Canadian government created legal distinctions between Aboriginal peoples who live on-reserve and off-reserve, that urban Aboriginal peoples face unequal and often discriminatory treatment when it comes to accessing government programs and funding designated for Aboriginal peoples. In many provinces where there is a high proportion of Aboriginal people working in urban areas, the provinces will be reluctant to agree to recognize the right to selfgovernment. They fear that they will lose control over revenues generated by urban Aboriginal peoples and/or federal monies.

In his paper on Financing Aboriginal Self-Government, Marc Malone identifies several potential methods and sources of funding which Aboriginal people could use to operate their governments. Some of these options would be unacceptable to Aboriginal peoples, while others would be unacceptable to government, but at the very least they give us an idea of the methods that could be used to generate funding.

1. THE SCOPE OF POSSIBLE RESOURCING

In the perspective of Aboriginal self-governing institutions, the following sources of revenue are, in theory, available:

(1) direct income tax powers in the personal and corporate fields;

(2) direct sales tax powers; 
(3) the sharing of federal and provincial income tax points:

(4) the sharing of provincial sales tax revenues;

(5) access to revenues accruing from resource development;

(6) municipal and regional-type taxation powers;

(7) unconditional federal and provincial "blockfunding" :

(8) federal/provincial transfers calculated on the E.P.F. "per capita" formula;

(9) indirect taxation;

(10) programme administration funds;

(11) special purpose grants;

(12) recourse to federal and provincial spending powers, and;

(13) profits derived from special ventures, utilities and enterprises. ${ }^{70}$

The current sources of funding for Aboriginal governments, which are First Nations governments under the Indian Act, are inadequate to meet the growing needs of their communities. Because of their special legal status, Aboriginal peoples who live on reserves have difficulties obtaining financing and generating revenue tr.rough normal means. Not to mention, the fact Aboriginal peoples have experienced discrimination from lending institutions and government programs designed to create economic development.

Sources of financing, like conventional borrowing, revenue raising and spending powers have not been made available to Aboriginal governments. The majority of reserve governments carry debt loads (it has risen $t$. well over $\$ 600$ million in ten years) and annual deficits." 
Not only are their governments in debt, but most communities never generate revenue to facilitate economic development which is independent of government sources and control. Aboriginal governments are fighting a losing battle to balance their books.

No matter how much we would like to believe otherwise, leading indicators show a widening gap in social, living and economic conditions between Aboriginal people and Canadians. It should be painfully obvious that simple tinkering with fiscal policies and programs cannot hope to achieve desired changes... Radical reform of fiscal policies and financing arrangements are needed more than ever. Those that cannot or do not want to see this inevitability are fooling themselves at the expense of Aboriginal people. ${ }^{76}$

Obviously, the government's policies of keeping Aboriginal peoples at subsistence levels financially are making a large impact on the communities. Not only must the government change its current methods of financing Aboriginal governments, but they must also provide Aboriginal people with the opportunities to generate their own funding.

One of the biggest fiscal mistakes of governments has been to treat Aboriginal communities as special interest or ethnic groups and not as distinct people with their own governments. Such a perspective will destroy and has destroyed attempts to improve relations and to work out problems in a cooperative fashion. side-stepping the fiscal autonomy of Aboriginal qovernments is risky business. (emphas is added).

If the government continues to under-fund Aboriginal governments, and to ignore their financial needs, Aboriginal communities will continue to deteriorate into ghettoes. Crime 
and social problems will escalate out of control and Aboriginal people will pay the price for their continued state of colcnial dependence.

Clearly, the fiscal relationship must radically change, if Aboriginal governments are to be strong and fiscally autonomous. It must be believed that this can be done... Several billion tax dollars each year are contributed by Aboriginal people, mostly living outside reserves. This is a major source of financing that is already paying for the basic benefits and services offered to these Aboriginal people... Much larger land and resource bases will provide an independent source of economic and tax revenue. Negotiated land settlements will provide major sources of financing for Aboriginal programs and services."

The Canadian government must look to revising its fiscal policies, especially in regard to economic development. They should consider the positive benefits which will have a ripple effect in the communities, if they help Aboriginal peoples to help themselves.

In order to develop a realistic idea of the potential costs that might be involved in setting up and running and Aboriginal government in an urban area, it was necessary to look at an existing institution. For example, if one took the Aboriginal population in the ottawa area, which is about 30,000 people as a starting point, and then looked the operating costs involved in a municipality of similar population size, one could get an idea of the potential annual costs involved in operating an urban Aboriginal government. 
It should be noted, however, that this does not involve startup costs such as purchasing a building, or office equipment, nor does it include the budgets for other programs and services which might be administered by an urban Aboriginal government. In this example, the Township of Cumberland, was selected as an example of what the cost might be to run a government office dealing with Aboriginal peoples living in the Ottawa area. This township has a population of about 40,000 people, which is roughly equivalent to the Aboriginal population in Ottawa. The operating budget for the 19921993, was approximately $\$ 18,000,000 . "$ Nearly $\$ 9,000,000$ dollars was raised through municipal taxation, which is a source of revenue that may not be available to urban Aboriginal governments. At least, this provides a financial figure to consider as an operating base in major urban areas. This estimate could be arrived at on a per capita basis, and/or as an annual operating budget to run an urban Aboriginal government.

Whatever methods are used to determine the costs of setting up an annual operating budget for an urban Aboriginal government, there will have to be additional sources of revenue. The methods by which this revenue is generated are sure to be of concern to both the Aboriginal peoples and government, as well as, a point of negotiation. 


\section{Coschusion}

The purpose of this paper was to discuss the concept of Aboriginal self-determination, and how it may be applied in urban areas. While the issues which have been discussed are complex, and at times confusing, it is an important discussion for those Aboriginal people who live in urban areas. Approximately 75 of Aboriginal population in Canada reside in urban areas, therefore a large number of people will be affected by any government policies which deal with their rights. The rights of Aboriginal peoples who live in urban areas are usually not recognized or protected, therefore they are in a vulnerable position.

Aboriginal peoples living in urban areas have to actively promote and protect their rights to equal treatment because the Canadian government, and in particular the Department of Indian Affairs and Northern Development, have policies in place which actively discriminate against Aboriginal peoples living off-reserve, and varlous other groups. There are also less obvious forms of discrimination and denial of their rights through the Indian Act. Aboriginal peoples firmly believe that as peoples within the context of international law, they have the right of self-determination and by implication, self-government. Aboriginal peoples believe that 
they are entitled to exercise those rights regardless of where they reside in Canada.

Aboriginal peoples living in urban areas should be entitled to equal access to programs and services whether they live on-reserve or off-reserve. The Canadian courts and the Indian Act have arbitrarily limited and restricted the rights that Aboriginal peoples are able to exercise, and this situation must be addressed. The legal distinctions that were created by the Indian Act and assimilationist government policies need to be changed because they created many inequalities which can no longer be tolerated. Aboriginal peoples living in urban areas should be included in any future discussions on Aboriginal self determination/self-government. They should be recognized as having legitimate concerns when their rights to self-determination are being discussed by other Aboriginal political organizations, and/or the Canadian government. They need to decide for themselves how they will move toward self-determination and what form it will take. Above all, they need to know that their rights are recognized and protected. 
Coolican, Murray. Living Treaties Lasting Aqreenents: Report of the Task Force to Review Comprehensive Claims Policy. Ottawa: DIAND, 1985.

Department of Indian Affairs and Northern Development. Indian Conditions: A Survey. Ottawa, Ont.: DIAND, 1980.

Federal Government of Canada. Your Guide to Canada's Proposed Constitutional Changes (the Charlottetown Accord). Ottawa, Ontario, August 28, 1992.

The Globe and Mail, September 7, 1993, p. A-17.

Indian Law Resource Center. Indian Rights Human Rights: Handbook for Indians on International Human Riohts Complaint Procedures. Washington, D.C.: Indian Law Resource Center, 1984 .

Little Bear, Leroy, Boldt, Menno, and Long, J. Anthony, eds. Pathways to Self-Determination: Canadian Indians and the Canadian State. Toronto: University of Toronto Press, 1989 .

Malone, Mark. Aboriginal Peoples and Constitutional Reform: Financing Aboriginal Self-Government in Canada . Kingston, Ontario: Institute of Intergovernmental Relations, Queen's University, 1986.

Morse, Brad, Vice-Principal, Legal opinion for N.A.F.C.. Ottawa, Ont., 1993.

National Association of Friendship Centres. Special Edition, 30th Annivereary of the Friendahio centre porement. Ottawa, Ont.: N.A.F.C., 1988. 
Native Council of Canada. Fiscal Relations and Arrangements: Aboriginal Patternse Trends and Answers. Ottawa, Ont.: Native Council of Canada, 1993.

Native Council of Canada, The Ongoing Dialogue: Meeting of Senior Provincial/Territorial Aboriginal and Federal officials Toronto: June 1-2, 1993. Toronto, Ont.: N.C.C., 1993 .

Ponting, Rick, ed. Arduous Journey: Canadian Indians and Decolonization. Toronto, Ont.: Mcclelland and Stewart Ltd. . 1986.

Richardson, Boyce, ed. Drumbeat: Anger and renewal in Indian Country. Toronto: Summerhill Press Ltd./Assembly of First Nations, 1989.

Royal Commission on Aboriginal Peoples. Aboriginal Peoples in Urban Centres. Ottawa, Ont.: Canada Communication Group, 1993.

Royal Commission on Aboriginal Peoples. Partners in Confederation: Aboriginal Peoples, Self-Government, and the Constitution. Ottawa, Ont.: August 18, 1993.

Royal Commission on Aboriginal Peoples. Public Hearings: Overview of the Second Round. Ottawa, Ont.: Michael Cassidy, Ginger Group Consultants, 1992.

Special Committee on Indian Self-Government, Chairman :Penner, Keith. Indian Self-Government in Canada: Report of the Special Committee. Ottawa, Ont.: Queen's Printer for Canada, 1983.

Township of Cumberland: 1993 Final Budget. 


\section{APPUNIX 2: Endnotes}

1. Aboriqinal Peoples in Urban Centres, p. 78.

2. Boyce Richardson, ed., Drumbeat: Anger and reriewal in Indian Country (Toronto: Summerhill Press Ltd./Assembly of First Nations, 1989), pp. 1-2.

3. National Association of Friendship Centres, Special Edition, 30 th Anniversary of the Friendship Centre Movement(Ottawa, Ont.: N.A.F.C., 1988), Pp.6-7.

4. Drumbeat, pp. 109-110.

5. Murray Coolican, Living Treaties Lasting Agreements: Report of the Task Force to Review Comprehensive Claims Policy (Ottawa: DIAND, 1985), Pp. 1-2.

6. Leroy Little Bear, Menno Boldt, and J. Anthony Long, eds., Pathways to Self-Determination: Canadian Indians and the Canadian State (Toronto: University of Toronto Press, 1989), p. xiv.

7. Special Committee on Indian Self-Government, Chairman: Keith Penner, Indian Self-Government in Canada: Report of the Special Committee (Ottawa, Ont.: Queen's Printer for Canada, 1983), pp. 40-41.

8. Royal Commission on Aboriginal Peoples, Partners in Confederation: Aboriginal Peoples, Self-Government, and the Constitution (Ottawa, Ont.: August 18, 1993), p. 45-46.

9. Partners in Confederation, p. 49.

10. Partners in Confederation, pp. 45-46. 
11. Indian Law Resource Center, Indian Rights Human Righte: Handbook for Indians on International Human Riohte Complaint Procedures (Washington, D.C.: Indian Law Resource Center,1984), pp. 58-59.

12. Penner Report, p. 17.

13. Royal Commission on Aboriginal Peoples, Aboriginal Peoples in Urban Centres (Ottawa, Ont.: Canada Communication Group, 1993), p. 9 .

14. Aboriginal Peoples in Urban Centres, p. 9.

15. Partners in Confederation, p. 3 .

16. Partners in Confederation, p. Preface.

17. The Globe and Mail, September 7, 1993, p. A-17.

18. Penner Report, p. 24.

19. Partners in Confederation, p. 36 .

20. Partners in Confederation, p. 36 .

21. Partners in Confederation, p. 9.

22. Penner Report, p. 40.

23. Partners in Confederation, p. 41.

24. Penner Report, p. 13.

25. Penner Report, p. 40. 
26. Penner Report, p. 13.

27. Rick Ponting, ed., Arduous Journey: Canadian Indians and Decolonization (Toronto, Ont.: McClelland and Stewart Ltd., 19861, p. 26.

28. Pathways, p.6.

29. Pathways, p. 3.

30. Pathways, pp. 3-4.

31. Federal govt. of Canada, Your Guide to Canada's Proposed Constitutional Changes (the Charlottetown Accord)(Ottawa, Ontario, August 28, 1992.), p. 6 .

32. Charlottetown Accord, p. 8.

33. Charlottetown Accord, p. 7.

34. Native Council of Canada, The Ongoing Dialoque: Meeting of Senior Provincial/Territorial Aboriginal and Federd officials Toronto: June 1-2, 1993, p. 1 .

35. Aboriginal Peoples in Urban Areas, p. 63.

36. Royal Commission on Aboriginal Peoples, Public Hearings: Overview of the Second Round (Ottawa, Ont.: Michael Cassidy, Ginger Group Consultants, 1992), pp. 31-32.

37. Aboriqinal Peoples in Urban Centres, p. 58.

38. Aboriginal Peoples in Urban Centres, p. 59.

39. Pathways to Self-Determination, p. xiv. 
40. Pathways to Self-Determination, p. xiv.

41. Pathways to Self-Determination, p. $x i$.

42. Pathways to Self-Determination, p. xv.

43. Partners in Confederation, p. 31 .

44. Partners in Confederation, p. 30 .

45. Partners in Confederation, p. 35.

46. Legal opinion on citizenship rights vs. membership rights, by Professor Bradford Morse, Vice-Principal, University of Ottawa Law School.

47. Partners in Confederation, p. 44.

48. Partners in Confederation, p. 45.

49. Aboriginal Peoples in Urban Centres, p. 57.

50. Aboriginal Peoples in Urban Centres, p.56.

51. Aboriginal Peoples in Urban Centres, p. 57.

52. Aboriginal Peoples in Urban Centres, p.78.

53. Aboriginal Peoples in Urban Centres, p.59-60.

54. Aboriginal Peoples in Urban Centres, p. 79.

55. Aboriginal Peoples in Urban Centres, p. 79. 
56. Aborlginal Peoples in Urban Centres, p. 60.

57. Partners in Confederation, p. v.

58. Partners in Confederation, p. 2-3.

59. The Globe and Mail, September 7, 1993, p. A-17.

60. Partners in Confederation, p. 42.

61. Partners in Confederation, p. 47.

62. Aboriginal Peoples in Urban Centres, pp. 4-5.

63. Partners in Confederation, p. 32 .

64. Federal govt. of Canada, Your Guide to Canada's Proposed Constitutional Changes (the Charlottetown Accord)(Ottawa, Ontar10, August 28, 1992.), p. 14 .

65. Partners in Confederation, p. 47.

66. Legal opinion by Professor Brad Morse, Vice-Principal, University of Ottawa, Law School.

67. Drumbeat, pp. 10-11.

68. DIAND, Indian Conditions: A Survey (Ottawa, Ont.: DIAND, 1980.), p. 3 .

69. Native Council of Canada, Fiscal Relations and Arrangements: Aboriginal Patterns, Trends and Answers ( Ottawa, Ont.: Native Council of Canada, 1993), p. 2 . 
70. Fiscal Relations and Arrangements: Aboriginal Patterns, Trends and Answers, p. 4.

71. Fiscal Relations and Arrangements: Aboriginal Patterns, Trends and Answers, pp. 2-3.

72. Fiscal Relations and Arrangements: Aboriginal Patterns, Trends and Answers, p. 4.

73. Fiscal Relations and Arrangements: Aboriginal Patterns, Trends and Answers, p. 4.

74. Marc Malone, Aborlginal Peoples and Constitutional Reform: Financing Aboriginal Self-Government in Canada (Kingston, Ontario: Institute of Intergovernmental Relations, Queen's University, 1986), pp. 35-36.

75. Aboriginal Peoples and Constitutional Reform: Financing Aboriqinal Self-Government in Canada, p. 4.

76. Aboriginal Peoples and Constitutional Reform: Financing Aboriginal Self-Government in Canada, p. 5 .

77. Aboriginal Peoples and Constitutional Reform: Financing Aboriqinal Self-Government in Canada, p. 6 .

78. Aboriginal Peoples and Constitutional Reform: Financing Aborlainal Self-Government in Canada, p. 11 .

79. Township of Cumberland: 1993 Final Budget, see appendix. 


\title{
19. APPENDIX 3: Title Page
}

\section{SELF-DETERMINATION: PROTBCTING THE RIGHTS}

OF ABORIGINAL PEOPLES IN URBAN AREAS

\section{BY}

CAROL STACEY-DIABO

B.A. Canadian Studies and Anthropology

A thesis subnitted to the Faculty of Graduate Studies and Research in partial fulfilment of the requirements for the degree of

\author{
Master of Arts \\ in Canadian Studies
}

\section{Carleton University}

OTTAWA, Ontario

(April 1995)

1995. Carol Stacey-Diabo 

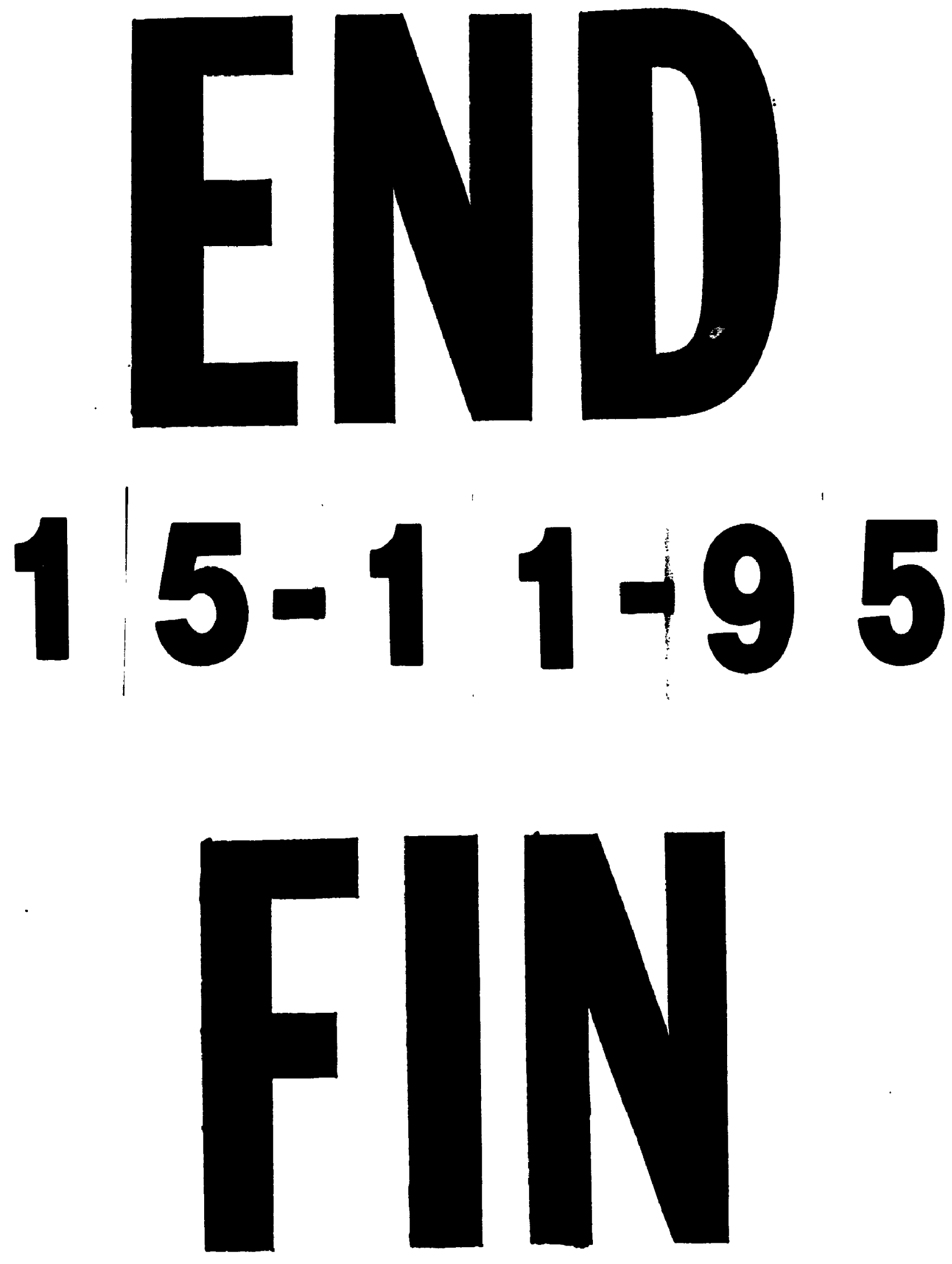